\title{
Navigating wicked water governance in the "solutionscape" of science, policy, practice, and participation
}

\author{
Amy L. Fallon $^{1}$, Bruce A. Lankford ${ }^{2}$ and Derek Weston ${ }^{3}$
}

\begin{abstract}
Many water sustainability and governance issues around the world can be viewed as wicked problems, whereby a solution, even if quite broad and comprehensive, may be contested because of high complexity, uncertainty, and diverging perspectives. These types of issues and their contestation thus create a complex landscape of possible solutions, which we term a water governance "solutionscape." We develop the concept of the solutionscape to identify different types of solutions that present themselves through the emphases placed upon four major dimensions: science, policy, practice, and participation. After first considering these four dimensions via a literature review, we then conceptualize the solutionscape's expressions comprising six different solution pathways. These are comprehensive solutions, where all four dimensions are equally supported and integrated; clumsy solutions, where multiple solutions are pursued separately without coordination (risking contradictions); two types of expedient solutions (high and low-cost), which involve attempts to pursue outcomes rapidly; solutionism, which refers to the over-emphasis of one dimension in an attempt to provide a quick-fix (leading to unintended consequences); and finally anti-solutions, whereby one or more dimensions are actively disputed or disregarded by policy makers. An example from South Africa is used to illustrate the framework's key components. We then discuss the allure of solutionism in solving wicked water problems, and how alternatives might be envisaged with the consideration of often-hidden institutional processes and power. Finally, we consider the value of the solutionscape as an integrative heuristic tool to discuss wicked water problems, recognizing issues such as plural perspectives and power asymmetries between stakeholders.
\end{abstract}

Key Words: complexity; Limpopo River Basin; South Africa; sustainability; transformation; wicked problems

\section{INTRODUCTION}

Navigating highly complex water problems facing society requires new thinking around the multiple causes of problems, and the diversity of perspectives and values involved, which, in turn, may open new insights about possible pathways toward better (and more accepted) solutions (Head 2010). Water problems often weave water and society together in a way that no single root cause of related complexity, uncertainty, or disagreement can be discerned (Rittel and Webber 1973, Liebman 1976, Head 2010, Pahl-Wostl et al. 2012, Grafton 2017). Meanwhile, global environmental change and rising socioeconomic pressures continue to jeopardize the capacity of freshwater systems to maintain both natural ecosystem functions and human development, including sustainable and equitable access (Vörösmarty et al. 2000, Rockström et al. 2009, Bogardi et al. 2012, Gosling and Arnell 2016, Kummu et al. 2016, Falkenmark et al. 2019).

How we govern such problems is influenced by multiple instruments, scales, users, and perspectives, few of which can be readily or easily coordinated together. The resultant social complexity and uncertainty that surround today's water challenges necessitate continuous negotiation in a landscape of solutions that span a multitude of worldviews and epistemologies imposing varying influences. However, this can be difficult in practice when policy, practices, and perspectives can be resistant to change, potentially stifling efforts to create innovative approaches and solutions needed for navigating such complexity (Moore 2013). The question therefore arises of how best to conceptualize, discuss, and navigate such issues when there is no single best approach, or where a single best approach is a matter of perspective and is thus disputed (Molle 2008, Head 2010).

\section{Water as a complex and "wicked" problem}

Freshwater systems are typically situated within a complex web of socio-political, economic, and environmental dynamics that influence how water is perceived, utilized, shared, and managed. The interconnectedness between both natural and human systems across temporal and spatial scales makes sustainability issues difficult to define comprehensively; freshwater governance is both a global and local issue because of its connections across sectors, places, and people (Akhmouch et al. 2018). Water's intricate relationship with society means that water issues occur in a social context with (at times radically) different values and goals, as well as differing interpretations of the problem, its causes, and how best to tackle it. This typically involves a plethora of public, private, and non-profit stakeholders with vested interests and varying levels of power to influence decision making. The resulting interest groups operate as agents with agential power within society, yet their often-incompatible interests, ideologies, and norms may make it difficult to break political deadlocks surrounding water resources utilization and management (Meissner 2005).

Water challenges are thus often described as "complex," in reference to their frequent uncertainty, lack of fixed or central hierarchy, surprising events, and interconnectivity with other issues in an open system, which may be ill-fitted to traditional problem-solving methodologies, such as technological fixes (Wallis and Ison 2011). Yet, these challenges may simultaneously be resistant to more innovative problem solving (that may be a better fit). A consequence of a historically technical and depoliticized discourse surrounding water governance is that when a river basin faces severe ecological disturbances with poorly understood causes, few tools are available to support responses 
in addressing the problem's political nature, as well as the inherent ethical and moral dilemmas surrounding how water is perceived and valued (Moore 2013). When such approaches become entrenched and resistant to change, it becomes difficult to create the innovative solutions necessary for dealing with complex problems (Moore 2013), for example, recent debates surrounding the generalizations of irrigation efficiency that may not suit local and specific irrigation problems (Lankford et al. 2020). However, it is important to note that a water problem's political nature does not automatically make it complex; indeed many river basin organizations are adept at dealing with political issues. Rather, it is the difficulty in understanding, defining, measuring, and resolving a solution (or solutions) to a problem that makes it complex.

Certain complex water issues may go further, being referred to as "wicked" problems, particularly as they become interconnected with large-scale environmental and economic issues such as climate change, where causal pathways become ambiguous and contested. The concept of wickedness provides insights for managing complex water problems that may be missed from more traditional problem-solving approaches based on assumptions of clear, linear causal relationships (Horn and Webber 2007, Batie 2008). Rittel and Webber (1973) proposed the term "wicked problems" to describe policy problems that defy rational solutions. Tame problems, on the other hand, may be complex and difficult, but can be clearly defined and solved by experts using analytical approaches of their given disciplines (Kreuter et al. 2004). Wicked problems are characterized by seven key features, whereby the problem is: dynamic and complex, defying comprehensive definition; unclear in its cause-effect relationships; unstable (a "moving target"); associated with an exhaustive list of solutions, but no clear or final solution; solved by solutions that may lead to unforeseen consequences; may be connected to (or a symptom of) a larger problem; and influenced by multiple and diverging perspectives, and a lack of consensus. Scholars have argued that the way to tackle such issues is through transdisciplinary approaches supported by "post-normal" science (e.g., Funtowicz and Ravetz 1993, Harris et al. 2010).

\section{Governing wicked water problems}

Recognizing such water challenges, water governance theory and policy must deal with issues such as complexity and uncertainty (Galaz 2007). Popular water policy paradigms such as integrated water resources management (IWRM), although comprehensive, have often been criticized for their inability to account for unpredictability and nonlinearity in water availability, as well as their inappropriateness in developing countries or in nonequilibrium and semi-arid environments (Galaz 2007, Lankford and Beale 2007, Biswas 2008, Molle 2008). There is also often a mismatch between policy goals and their outcomes (Förster et al. 2017). Institutional procrastination may also occur during planning and implementation, whereby attempts to achieve a full integration of water and related issues, e.g., energy and land-use, slow down meaningful change (Lankford and Hepworth 2010). Despite its promises, IWRM implementation has been impaired by technocratic and procedural solutions that do not adequately incorporate issues of equity and justice (D. Gyawali 2020, blog, http://www.water-alternatives.org/index.php/blog/nexus). Similar concerns have been raised regarding recent nexus approaches, such as the water-energy-food nexus, which are equally at risk of "silo practitioners filtering out uncomfortable knowledge around social injustice and powerful hegemonies that marginalize the weak" (D. Gyawali 2020, blog).

The top-down nature of such policy implementation may neglect the need for, and benefits of, collaborative and participatory processes in understanding and negotiating social and environmental complexity, though this has been discussed throughout environmental governance literature (Green and Chambers 2007, Reed 2008). Theoretically, such issues have been explored through, for example, Kooiman et al.'s (2005) interactive governance framework, which assesses a system's governability by considering its complexity, diversity, dynamism, and scale (Kooiman et al. 2005, 2008, Jentoft and Chuenpagdee 2015). Meanwhile, adaptive and collaborative water governance focus on participatory processes and learning cycles in order to reconcile a diversity of perspectives, priorities, and knowledge amongst stakeholders, as well as facilitating changes in procedure (Pahl-Wostl et al. 2012, Harrington 2017). There remains, however, a need for more transdisciplinary approaches that incorporate an understanding of social behavior and practices by policy makers, an ability to tolerate uncertainty, and the need for a long-term focus with no quick fixes (Head 2010). Big-picture thinking around water governance may therefore be instrumental to understanding how we think about, and deal with, wicked problems.

Recognizing this, we reconceptualize a contested landscape of possible solutions into a "solutionscape," defined as a deliberative space that welcomes discussion of competing solutions, contradictory convictions, (in)appropriate decisions, and policy (in)decisiveness and (in)action. This solutionscape has four key dimensions: science and research; policy, policy makers, and policy partnerships; practice and technology; and participation and engagement. We then present six typical solution-types that commonly play out depending on context: comprehensive solutions, where all four dimensions are equally supported and integrated (albeit bringing costs); clumsy solutions, where solutions are uncoordinated but are low-cost in comparison; expedient solutions (both high and low cost versions), which involve two or three dimensions in an attempt to pursue outcomes rapidly; solutionism, which refers to the overemphasis on one dimension as an attempt to provide a quick-fix (often leading to unintended consequences); and finally anti-solutions, whereby one or more dimensions are actively disputed or disregarded by powerful actors (often being politically advantageous to them).

We use an example from South Africa to illustrate how the framework may be applied, and what can be gained from it. Through the case study and framework, we ask the question of how we can comprehend wicked water problems not as problems to be definitively solved in a one-size-fits-all approach, but as environmental, cultural, and political phenomena that can reshape the ways in which we think about and transform watersociety relations.

\section{METHODS}

For this study, we reviewed relevant literature concerning environmental, and more specifically water governance, which informed the core dimensions of the solutionscape framework. The framework is built from a political-ecological perspective, placing environmental problems in their social, political, and 
economic contexts, thus developing more socially relevant understandings (Forsyth 2003). We also draw on social constructivism, emphasizing the central role of epistemic communities and related knowledge production and discourse around wicked problems.

The framework is informed by the authors' expertise in water resources management, and illustrated through a case study from South Africa, a key research area for the authors. This is partly based on primary data collected between 2014 and 2016 through interviews and workshops with key stakeholders, including farmers, representatives of the Department of Water and Sanitation (DWS), members of an agricultural union, and representatives of the Department of Land Reform and Rural Affairs. This was complemented with participant observation of farmers' water management strategies and perspectives. National water laws, policy documents, and other grey literature were also used for analyzing South Africa's water policy.

\section{Case study: the Doringlaagte, South Africa}

The Doringlaagte is a small sub-catchment of the Hout Catchment within the Limpopo River Basin, which supports groundwater irrigation on commercial farms (potatoes being the main crop) and some smallholder farming, as well as communities on the outskirts of the catchment around the town Mogwadi (previously known as Dendron; Fallon et al. 2019). Extensive groundwater pumping since the 1950s has impacted its shallow aquifer, though the extent of damage is contested because of insufficient data, complex hydrogeology, and conflicting perspectives (Jolly 1986, Masiyandima et al. 2002, Fallon et al. 2019). Water in the area is primarily managed by the farmers themselves through an agricultural union, though there have been issues raised regarding the effectiveness of both formal and informal strategies undertaken (Fallon et al. 2019; see Appendix 1 for a map of the study area).

On the surface, the area's water problems appear to be welldefined, i.e., unsustainable groundwater irrigation; however, it is in fact more complex, and even wicked because of issues such as low data and conflicting perspectives. The hydrogeology of the aquifer remains uncertain, leading to contrasting views of the aquifer's status. Some farmers interviewed felt there was no problem, while others were increasingly worried about increasingly frequent drought events and depleting water levels. Meanwhile, recent modeling suggests a more cyclical and dynamic nature of the aquifer's recharge, rather than straightforward overabstraction (Ebrahim et al. 2019). However, increasing climate variability and more frequent drought events may make recharge dynamics more difficult to discern. This is primarily because the aquifer is shallow and therefore influenced by rainfall, and it has been estimated that current abstraction rates are close to the aquifer's sustainable yield.

The area's water problem exists within a complex socio-political context, and is symptomatic of South Africa's broader water (and other natural resource) problems. South Africa's transformative post-apartheid reforms of its water laws and policies, e.g., the replacement of the discriminatory 1956 Water Act with the 1998 National Water Act (NWA), were deemed highly progressive. However, implementation has been weak, and clauses such as "existing lawful use" have been criticized for providing legal loopholes for earlier water allocations based on riparian rights (van Koppen and Schreiner 2014). Goals of decentralized water management, e.g., through catchment management agencies, have not been realized because of poor target-setting and accountability, underestimation of the complexities of departmental and sectoral transformation, and lack of capacity, particularly in DWS (Schreiner 2013).

\section{A REVIEW OF FOUR CORE DIMENSIONS OF THE SOLUTIONSCAPE}

The core concept of the solutionscape is water governance, which can be defined as the outcome of socio-political processes aimed at finding solutions to collective water problems, formulated across the macro level of policy formulation, the meso level of institutional implementation, and the micro level of social dynamics around water (Saravanan 2010). Water governance encompasses the political, social, economic, technological, and administrative institutions that influence and shape water resource use and management practices across society (Haas 1992, Rogers and Hall 2003, OECD 2015). Here, institutions refer to the "rules of the game," or social constraints to human interaction (North 1990, Haas 2016). Cleaver (1999) classifies institutions into "bureaucratic institutions," referring to the formalized arrangements based on organizational structures and legal rights, and "socially embedded institutions" that are based on history and culture, (informal) social organization, and daily practices. The nature of wicked water problems means governance must be able to deal with issues of complexity, uncertainty, and multiple (often conflicting) perspectives and epistemologies. We present water governance as a dynamic process, rather than a linear procedure toward a specific policy-goal or a list of desirable attributes (for example, as per OECD [2015] guidelines).

We believe this dynamic process, and therefore the solutionscape, emerges through the interaction of four core dimensions: science, policy, practice, and participation. These are discussed below and although appear in the order of "one to four," we stress the nonlinear, or circular, relationships between the four dimensions. In other words, in its conceptual format, no hierarchy between the four dimensions applies. However, in reality and as explained, we very much accept that one or more dimensions might trump others.

Prior to our explanation of each dimension, we note they are each aligned to an epistemic community and the associated activities shaping how water policy is constructed and delivered. Epistemic communities (ECs) are networks of knowledge-based communities with shared perspectives, competencies, and preferences over a policy issue (Haas 1992). This may include (though not limited to) researchers, lawyers, managers, activists, and government officials (Baumgartner and Pahl-Wostl 2013). Grounded in social theory, the concept of ECs stems from the social constructivist view that actors' perceptions do not correspond fully to a realistic (or positivist) depiction of the world, because of their personal worldviews, interests, and an inability to fully comprehend the complexity or uncertainty of the problem at hand (Haas 1992, 2016). This EC perspective reveals hidden forces of governance, delving deeper than the observed bureaucratic institutions (such as policies and laws) into a background domain of information, discourses, norms, and values, all of which are potentially less transparent and legitimate (Baumgartner and Pahl-Wostl 2013). 


\section{Science and research}

The first governance dimension is science and research. We argue its placement within the solutionscape is key because without an effective promulgation and communication of high-quality research of complex water problems, the other three dimensions run the risk of being incorrect or inappropriate for a given set of circumstances. We analyze science and research via three matters: how science can support policy, participation, and practice (through varying degrees of influence); the limitations of scientific knowledge in decision-making processes; and the risks of politicized science.

First, the support science provides policy makers largely depends upon the stance taken by scientists regarding the science-policy boundary and their position along it. There are four different roles that scientists can play in influencing policy, based on Pielke's (2007) and Campbell Keller's (2009) categorizations:

1. the pure scientist, who focuses on research with no consideration for its use in society or policy making (a "boundary avoider");

2. the science arbiter, who seeks to stay separate from policy and politics, but recognizes that decision makers may have specific questions relating to their research (a "boundary observer");

3. the issue advocate, who focuses on the implications of their research for a particular political agenda, and actively participates in the decision-making process (an "unapologetic boundary crosser"); and

4. the honest broker of policy alternatives, who engages in decision making by expanding the scope of policy options, and seeks to integrate scientific knowledge with societal concerns (an "apologetic boundary crosser").

The pure scientists and science arbiters typically play a background role in policy making, representing science in its purest form as a "reservoir of knowledge" (Pielke 2007:15). They have little direct connection with decision makers unless called upon to answer specific questions from an expert perspective. Such information is seen as politically impartial, with the power to catalyze meaningful governance reforms (Kosack and Fung 2014). The stance of the pure scientist is grounded in a traditional, relativist model of science in policy making, where science is not used until after policy goals are set, and the focus is on finding the most effective or efficient means to reach them (Campbell Keller 2009). Meanwhile, the science arbiter typically holds a logical positivist perspective, in which science is used to resolve policy controversies with an objective, correct view of reality. This is particularly seen in water policy making that uses science to support technocratic solutions for efficiently allocating resources. The key assumption here is that by increasing scientific knowledge and reducing uncertainty, policy will follow suit: "anyone with the proper training and the proper methodological tools would arrive at the same incontrovertible endpoint" (Campbell Keller 2009:30). Scientists may then see their role as neutral and objective, speaking truth to power, yet this narrative neglects the two-way nature of knowledge production and communication between scientists and policy makers (Hoppe and Wesselink 2014).
Scientists may also act as issue advocates, either consciously or unconsciously crossing the science-policy boundary. This may be beneficial in the case of wicked water problems, where uncertainties and decision stakes are high, and thus those who have a deeper understanding of complexities are well-suited to guide policy. This can be found particularly in the agenda-setting phase, when scientists often use narratives, e.g., a state of environmental decline, and causal stories, e.g., drawing clear links between problems and solutions, to advocate for increased policy focus on a particular issue (Stone 1989, Campbell Keller 2009).

The fourth category of scientists seeks to open up the scope of policy options (the honest broker). From this perspective, researchers use more integrative approaches, and are often engaged in cyclical social learning processes with policy makers from an early stage (Vogel et al. 2007, Allan 2008, Armitage et al. 2015, Meadow et al. 2015). Such an integrated approach in water research may address uncertainties or diversity in society and the environment, or include water resources that are less-easily controlled (Zeitoun et al. 2016). This may result in more diverse and inclusive policy recommendations, as opposed to limited policy interventions that are too rigid for non-stationary environments that can reproduce inequalities (Zeitoun et al. 2016). Furthermore, more integrative approaches in water research that investigate the role of power and justice in institutional arrangements could support policy makers in broadening their understanding of wicked (water) problems (Cleaver 2012, 2018, Meissner 2016a, Cleaver and Whaley 2018).

Mediating the science-policy interface may be done via boundary organizations (e.g., policy-relevant research institutes), boundary objects (e.g., the IPCC's emissions scenarios), or boundary processes. These can facilitate communication between science and policy making in legitimate ways, instead of attempting to separate them (Pielke 2007, Berkes 2009, Campbell Keller 2009, Girod et al. 2009, Hoppe and Wesselink 2014, Gustafsson and Lidskog 2018). Blurring the boundary between science and politics, rather than separating them, can lead to more productive policy making (Guston 2001). However, Cash et al. (2003) suggest that such boundary work must balance credibility, salience, and legitimacy at the science-policy interface.

Finally, research/researchers may play a supportive role to the participation dimension of the solutionscape through the empowerment of local resource users to take ownership of their collective water issues. For example, scientists may collaborate with local users through methods such as participatory mapping, workshops, and citizen science, not only to gain local insights, but to encourage involvement of local actors in the process. Increasingly, scientists are recognizing the need for including different knowledge types beyond their disciplines, including traditional and indigenous knowledge, and the importance of transdisciplinarity (Harris et al. 2010). Research may also support practice through policy implementation, as well as innovation and technology development (see below section on practice).

Limits of science in (water) governance

However, the role of scientists and scientific research in governance is not always advantageous, or simple. First, scientists often simplify or overstate their findings, or present them as a single definitive interpretation, which is often assumed to be most 
useful to policy makers (Stirling 2010). This is understandable; the ability to portray a policy issue as resolvable is crucial in getting it on the policy agenda (Campbell Keller 2009). Yet, there is no definitive solution to wicked problems, and attempts to translate science into understandable, policy-relevant information may come at the cost of quality or nuance. Complex causal explanations are not very useful in politics because they do not offer simple causes or a "single locus of control" (Stone 1989:289). This is often dealt with within the scientific sphere by calling for more research or more knowledge. In water policy and research, the search for clarity and consensus may also emerge through more reductionist approaches to water-society challenges, along with specific and generalizable policy prescriptions (Zeitoun et al. 2016). For example, water-related risks may be oversimplified, along with an "inappropriately narrow focus on probability" (often in response to incomplete knowledge), as seen in studies that too confidently link national GDP with hydro-climatic causes (Zeitoun et al. 2016:145). Stirling (2010) argues that scientists must, however, keep it complex when knowledge is uncertain, and avoid oversimplifying their research findings. Yet, it is still important to ensure research is salient and accessible to decision makers, which is no easy task (Kosack and Fung 2014).

Second, in political contexts facing significant value conflicts, science offers "less prospect of contributing to effective decisionmaking" (Pielke 2007:53). In such situations, scientists may retreat into the role of the pure scientist so as to avoid involvement in political debate, i.e., to maintain separation between science and policy, which is arguably impossible (Pielke 2007, Vogel et al. 2007). However, such efforts may actually foster the (unintended) politicization of science, and scientists may (consciously or unconsciously) hide their own advocacy in the guise of pure science; scientists should therefore be clear on the choices they make regarding their position on the science-policy boundary.

The allure of the pure scientist label may also reinforce reductionist approaches to water research grounded in engineering and economic disciplines. Although an important component, such approaches alone are incapable of dealing with complex, and often highly political, water problems. A positivist lens is inadequate in understanding environmental complexity (Meissner 2016b), and thus researchers increasingly cross disciplines to include, for example, political and social sciences (e.g., see Mollinga 2001, Mollinga et al. 2007, Zeitoun et al. 2016).

On the other hand, issue advocates within the scientific community may use science narratives to push certain policy agendas they deem important, and portray them as objective products of research, and thus neglect the social and political context shaping them (Stone 1989). This is particularly common in environmental research and policy making, as seen in the climate change policy sphere. Scientists may (inadvertently) allow their own personal biases, beliefs, and ideologies to shape their engagement in the policy sphere, and incorporate subjective judgements into the advice their offer while maintaining their expert label and symbolic, privileged position (Campbell Keller 2009). Alternatively, this boundary-crossing may be purposeful, driven by scientists' desire to speak truth to power (rooted in a positivist view of science's ability to provide the correct view of reality).

Policy makers at times also push scientists for definitive answers, who in turn adopt one of three coping strategies in response: they acquiesce; they answer as citizens rather than scientists; or they find a way to avoid responding directly (Campbell Keller 2009). Scientists often lack training in non-scientific communication to deal with such situations, while practitioners may lack the technical expertise needed to comprehend implications of scientific research and terminology such as uncertainty (Vogel et al. 2007). Thus, a scientist's role in policy making must be continually negotiated, depending on context, particularly whether they should be allowed to express policy preferences, or even maintain their privileged position as objective actors offering universal information (Campbell Keller 2009).

Science may also undermine participation in water governance because science communication still errs to the side of persuasion from the expert's perspective, rather than collaboratively defining problems and solutions (Vogel et al. 2007). A "we know best" attitude of scientists remains a problem, with conflicting notions of legitimate knowledge (Cleaver 1999, Briggs 2005). Such bias can prevent the questioning of basic assumptions and the exploration of alternative worldviews (Fischer 2000). Although scientists can help us understand the connections between available policy options and their outcomes, scientific information alone is rarely enough for providing certainty to policy recommendations (Funtowicz and Ravetz 1993). Policy making depends on multiple conceptions of the world we want to create. Meanwhile, some mainstream theoretical and paradigmatic approaches "do not sail well when they meet the turbulent 'everyday' waters of free will and agency driven by power politics" (Meissner 2016b:422). Ideally, water governance would refer to multiple knowledge types distributed across many actors (with varying levels of power and influence), making it challenging for any one actor or group of actors to dominate decision making (a water project could, therefore, require input from hydrologists, engineers, government, farmers, social scientists, and local industry). A transdisciplinary approach to water governance that emphasizes the importance of broad participation is important, particularly in wicked settings (Harris et al. 2010).

\section{Policy, policy makers, and policy partnerships}

Regarding our second dimension, we outline how policy and policy makers can more effectively support science, practice, and participation, followed by potential pitfalls (the topic of policy partnerships is covered below). Water policy refers to the iterative process of multi-level legislative and regulatory design for managing water resources, including the often-non-harmonious nature of stakeholder interaction regarding how they feel water resources should be governed. Key stakeholders involved in this are policy makers at national and international levels, regional or local water managers, the public (through consultations), as well as non-governmental organizations (NGOs) and the private sector. Policy making includes the formulation of a range of water management instruments and principles at strategic and operational levels, and that guide multi-lateral agreements, integrated planning, sectoral water allocations, water rights and permitting, conflict resolution mechanisms, and approaches to water governance.

In an ideal situation, policy supports science through collaborative interactions between policy makers and researchers via the science-policy interface (Armitage et al. 2015). Policy makers may guide and procure research agendas toward policy- 
relevant research questions, provide funding for policy-relevant research, and request inputs from scientists on specific issues (Lankford et al. 2020). In order for this to be effective, policy makers should have an understanding of the imperfect nature of science (Sutherland et al. 2013). The cyclical interaction of policy makers and scientists enables knowledge co-production, providing opportunities for learning across both stakeholder groups and coordinated action around a water problem. Water policy supports practice by providing the legal framework within which management activities operate, strategies to adhere to, and capacity-building practices. Policy makers also facilitate the funding of infrastructure projects and administrative duties. Furthermore, policy can support participation by formalizing the involvement of local people in decision-making processes. Such relationship-building can also promote trust, transparency, and legitimacy, if power asymmetries between actors are accounted for and appropriately challenged both in the writing and implementation of water policy (for example, through the prioritization of indigenous water rights). Policy makers can also ensure water policies are tailored to local environmental contexts with support by and interaction with local water users, for example, through citizen science.

Included within policy is the subject of policy partnerships. This is because partnerships between policy makers and non-state actors are playing an increasing role in water governance, both in policy design and delivery. Although there is a corporate need to manage various water-related risks, the private sector is increasingly recognizing the importance of supporting government as a part of their license to operate. This is also being underpinned by government policies that are reflecting the importance of private sector engagement to support more effective, and potentially more integrated water management. Corporate water stewardship is also an example of policy partnership involving non-traditional, private actors in water management (Hepworth and Orr 2013). These partnerships can take various forms and often seem to have more traction at local catchment levels, and this has realized an increasing inclusion of private sector businesses into more formal water management procedures at these levels. For example, a growing number of water-using businesses in South Africa have engaged in corporate water stewardship initiatives such as catchment-based forums (Sojamo 2015). However, the political nature of governance remains an issue, with powerful stakeholders able to hijack the policy process to legitimize their own agenda.

Limits of policy in (water) governance

Water policy is at times ill-tailored to local environmental and socio-political contexts, leading to issues in its effectiveness (particularly in developing countries). For example, policy paradigms such as IWRM (and to some extent, nexus approaches) are often criticized for their centralized, regulatory approach, which is best suited to temperate or oceanic climates, where water resources are not typically constrained, and authorities have substantial financial, human, and technological capacities (Grey and Sadoff 2007, Lankford and Hepworth 2010; D. Gyawali 2020, blog). It is therefore questionable as to whether it is appropriate to implement IWRM in regions such as southern Africa, where climate variability is high, institutional capacity often inadequate, and data availability low (Lankford and Hepworth 2010). Furthermore, the more integrated such paradigms are made, the harder they are to implement.
The role of power in water policy processes between state and non-state actors also remains a challenge (e.g., Molle 2008, Zeitoun and Warner 2006, Zeitoun 2011). Bureaucratic approaches to water policy making in developing countries are often driven by government agencies as the main stakeholders, leaving little room for less organized, informal interests. This may perpetuate water deprivation as a central element of poverty, and a continued dependence on the "random goodwill of the state" (Wester 2008:170). The role of scientific research is again relevant here; increased use of social theory and more integrative approaches in the research that supports policy makers could open options for decision making beyond the positivist perspectives that are increasingly criticized (Cleaver 2012, Meissner 2016a, Cleaver and Whaley 2018).

Thus, we argue that if water policy is inadequately deliberated, the other three dimensions of science, practice, and participation will be undermined. For example, if policy makers do not understand the imperfect nature of science, they may inappropriately coax scientists for definitive answers (simultaneously neglecting to emphasize participation and a wider discussion). Policy makers may thus view scientists as "hired guns" bringing cherry-picked data to support their ideological stance, while suppressing other voices (Pielke 2007).

\section{Practice and technology}

For our third dimension, we define practice in four interconnected ways. First, and primarily, we see practice as the operational management actions taken on the ground, based on principles of water governance, i.e., the movement from vision to action, or from policy to strategy and implementation (through a process of change). Water resources management may be viewed as a "practice in which structure and agency 'meet' to reproduce and transform society" (Mollinga 2008:11). Second, practices are the "seemingly mundane routinized sets of social action" that occur as a result of the interplay of actors' inner structures, their ability to act, and the social context, all of which can impact policy and its implementation (Bourdieu 1977, Ober and Sakdapolrak 2017:360). In this way, practice can be seen as stable and the fundamental level of individual behavior (e.g., see Bourdieu 1977, Bueger and Gadinger 2015, Kustermans 2016). Discursive practices are also important here, i.e., the practices of knowledge formation, or discourses (Bacchi and Bonham 2014). If they become dominant, discourses may consequently shape and form social practices, including beliefs, norms, and values. For example, water practitioners use prevailing "paradigms and theories as a foundation for their thinking and practice" (Meissner 2016a:1346), alongside collectively understood best practices (Molle 2008). Third, practice can be understood through practical knowledge, pertaining to the skills acquired through experience (Kustermans 2016).

Fourth, we link technology to practice because they co-construct each other; in other words, advances in water technologies (e.g., smartphone payment services) shape how service providers practically provide their services and vice versa - constraints in practice drive technology innovations (e.g., as shown by Koehler et al. 2015). We emphasize practice and technology because definitions of "good" water governance are at times abstract, and lack enquiry and understanding of how things work "in practice" (Franks and Cleaver 2007). Whereas theory is seen as tidy, practice is the messy reality (Kustermans 2016). 


\section{Limits of practice in (water) governance}

We now address two sub-issues: how practice supports the other three solutionscape dimensions, and the potential problems that may arise when done inappropriately. Practice, as we have portrayed it through the behavior and activities of water practitioners, can support science and research through collaborative technological innovation, and information and data-sharing. It also plays a vital role in policy through implementation of strategies and delegated operational activities, such as regional water departments (it is of course important to note that science and policy are practices in and of themselves). Practice may also support participation in water governance through local employment and monitoring activities. Stakeholders involved vary widely depending on context, but typically include public sector institutions, private sector actors, and civil society groups, for example, water companies (publicly or privately owned), NGOs involved in water, sanitation, and hygiene (WASH) projects at a local level, and water user associations managing water abstractions for multiple uses. Responsibilities include infrastructure maintenance, administrative actions, and monitoring networks. The suitability of practice and technology is influenced by the comprehensiveness of stakeholders' understanding of water issues within a catchment, as well as the infrastructure already in place.

When practitioners lack (scientific) expertise (for example, poor hydrogeological understanding of an aquifer), inadequate decisions and management practices may follow. Furthermore, practical knowledge is also a vital component in water governance; it is grounded in social realities, and often seen as common sense, as opposed to the sometimes-detached knowledge derived from scientific practices. For example, practical knowledge of water practitioners may include understanding the actors they are working with, and the specific socio-political context they are working within.

Similarly, implementation of policies that are not sufficiently grounded in existing social practices will be challenging, or may cause further unanticipated issues. Furthermore, practitioners may lack the human or financial resources necessary for proper policy implementation. This is particularly an issue in developing countries, where institutional capacity is often low (Lankford and Hepworth 2010). Finally, in terms of discursive practice, problems may arise if water practitioners do not critically reflect upon dominant water governance discourses, or if they re-appropriate and repackage concepts to fit their own agendas and needs, for example, as seen in uncritical uses of irrigation efficiency in highlevel water policy (Lankford et al. 2020). This again highlights the role of politics and power in water management practices (Molle 2008).

\section{Participation and engagement}

Our fourth dimension of the solutionscape is participation and engagement, which we define as both a policy intention and delivery mechanism. Effective engagement of stakeholders and citizens is important in both understanding the multiple dimensions of wicked water problems, and identifying solutions (Head 2010). Ideals of participation in water may best be captured via the normative statements on participation that arose out of the Dublin 1992 Conference (World Meteorological Organization 1992). The emphasis given to participation in that conference, and in subsequent IWRM programs around the world, could be traced to its two main benefits: (1) it increases the diversity of knowledge types available to decision makers and researchers; (2) it empowers local water users to take responsibility for solving their own water problems (Wester et al. 2003) and as such may support social transformation (e.g., see Cleaver 1999, Franks and Cleaver 2007, Garduño et al. 2010, Wehn et al. 2018). These two potential benefits are explored in turn, followed by the common pitfalls surrounding participation.

Ideally, participation can support water policy by increasing the inclusion of local knowledge in formal decision making; local resource users frequently hold a different understanding of their natural environment than incoming experts, and are often adept at predicting and adapting to environmental change (Bocking 2004). This can be useful to decision makers with limited local environmental understandings. Furthermore, participatory processes can go beyond late-stage consultations to empower local stakeholders in influencing agenda setting in the early stages of policy development (e.g., Fung 2006). This more active participatory role is referred to as "enfranchisement" by Green and Chambers (2007). Participation may thereby increase trust and accountability within water governance arrangements, as well as ensure successful policy implementation. This takes a crucial step away from the simple request for more participation, toward a more thoughtful involvement of stakeholders in recognizing their relative power and responsibilities.

Furthermore, a participatory research approach can also support science by providing diverse and local understandings of natural resource use (including defining the problem), for example, through citizen science, workshops, participatory mapping, or data-sharing. An increase in such post-normal science ensures the consideration of a plurality of perspectives around resource-use, moving away from reductionist understandings of a problem (Funtowicz and Ravetz 1993). Amid technical details, it is easy to lose sight of non-technical objectives such as equity; water research must therefore retain a human face (Mason and Calow 2012). For example, research from a social constructivist perspective could benefit water research through its focus on normative issues such as ideology, values, interests, and culture, as well as the role of non-state actors (Meissner 2014).

Normatively, participation may improve practice by empowering local water users to take responsibility for solving their own water problems. For example, water users may take a substantial role in infrastructure improvement through artisanal construction, assisting with logistics or via employment with water organizations. They may also share data that is beneficial for monitoring and evaluation. Such involvement may encourage work toward deeper social transformation (Wester et al. 2003).

\section{Limits of participation in (water) governance}

However, we identify three issues that may affect the success of participation, and potentially undermine the efficacy of the other three dimensions. First, uncritical "check-box" inclusion of local water users in decision making can give the impression of "good" participation, but in reality, may be mere tokenism (Wester and Bron 1998), which is a problem sometimes found in environmental and social impact assessments. Such uncritical participation (whether conducted consciously or unconsciously) can maintain the status quo rather than achieve participatory goals of social 
change or transformation (Leal 2010). As stated by White (1996:7), "incorporation, rather than exclusion, is the best form of control." Incomplete community participation and late consultation may also lead to a mismatch between scientific research and local needs, and incomplete understandings of local environments (Vogel et al. 2007). This may go further to total exclusion if researchers do not adopt a participatory approach to begin with. Instead, there may be an overreliance on technical expertise and the positivist paradigm because of the appeal of committing to the scientific method, even in contexts where social scientific approaches are more fitting (Briggs 2005, Huitema et al. 2009, Meissner 2016a).

Second, the need for participation can be emphasized, yet still fail to empower all water users if it does not appropriately deal with asymmetries in power and influence. If messy realities are ignored and sanitized, decision making will keep benefiting the most powerful, for example, as observed in the (attempted) establishment of water user associations (WUA) in South Africa (Förster et al. 2017, Fallon et al. 2019). The participation discourse tends to conceal water's nature as a politically contested resource (Mehta 2000, Mollinga 2001). Decision making is predominantly seen as a step-by-step process of rational thinking, rather than embedded within the messy reality of human democratic systems, the ongoing conversational activities grounded in ideology, power, and emotional and social processes (Stacey 2011). Legal rights do not necessarily ensure effective contribution, and rules and practices surrounding participation can be varied, with influence often limited to a few key groups. If the differences between stakeholders - in terms of language, politics, and beliefs about how nature and society function-are not taken into account in water management when creating new rules, roles, and rights, the participatory processes may further institutionalize power differentials (Wester et al. 2003). This also applies within groups, where power differentials can be just as vast and equally hidden.

Finally, participation may become an "act of faith in development" that we rarely question (Cleaver 1999:597). Here, local expertise may be romanticized, while technical support is neglected. Yet, there are often limitations to participants' influence over the wider structural factors shaping water and development projects, meaning terms such as "empowerment" lose their radical and transformational edge (Cleaver 1999, Leal 2010). Furthermore, there are questions regarding who is to be empowered, and how they can exercise agency, again emphasizing issues of power asymmetries within communities. This must involve more than merely requiring the marginalized to sit on decision making committees (Cleaver 1999). However, there remains a tendency to concentrate on building formal water institutions, despite discussions around the importance of social and informal activities, including daily interactions and social networks and norms (Cleaver 1995, 1999, 2000, Mosse 1995, Goebbel 1998). Additionally, unpacking motives and incentives for participation seek to go beyond the assumption that people will want to participate in water and broader development projects "for their own good" (Cleaver 1999:605). Participation can also be involuntary, for example, because of biophysical water scarcity. Despite this, there remains a strong focus on economic rationality as the primary motivation for participation.

\section{RESPONDING TO WICKED WATER PROBLEMS IN THE SOLUTIONSCAPE}

Figure 1 conceptualizes the solutionscape for water governance, within which science, policy, practice, and participation interact to determine the outcome of processes aimed at solving a collective (water) problem. In reality, there are not clear divides or directions of travel between practitioners, researchers, government officials, and water users, and interactions between them occur in complex, ever-changing webs of connection across scales (characterized by the grey context sphere).

The spheres, representing each dimension of the solutionscape, consist of differing behaviors, decisions, and actions (detailed in the boxes next to each sphere), and can change in size depending on their level of comprehensiveness and fit. For example, if there are gaps in licensing and regulation of water-use, the "policy, policy makers, and partnerships" sphere may be smaller. The grey sphere is the (theoretical) space where these four dimensions interact.

\section{Solutionscape expressions}

Using the solutionscape conceptualization, we identify six possible expressions, depending upon the emphasis placed on one or more dimensions: comprehensive solutions, clumsy solutions, expedient solutions (both high-cost and low-cost), solutionism, and anti-solutions. These expressions are not fixed, and rather the solutionscape is a dynamic space within which solutions are constantly sought after and contested. Within each expression, the four governance components interact in differing ways, with some gaining more support and attention than others, as shown in Fig. 2.

Here, we explain what each solution-type from the solutionscape (Fig. 2) entails:

\section{Comprehensive balanced solutions (high-cost)}

For a solution to be balanced and comprehensive, all four governance components must be equally supported and integrated. The resulting solution is usually expensive to implement because of high implementation, capital, operational, and transaction costs. This requires strong interactions between the four governance components, utilizing a wide range of perspectives, knowledge types, and needs toward a collective goal. However, there remains a risk of overcomplicating the issue or including so many stakeholders that a political deadlock is reached because of the sheer scale, complexity, or an unattainable idealization, of the solution, for example, as seen in South Africa's difficult process of establishing catchment management agencies (Schreiner 2013, Meissner et al. 2016).

\section{Clumsy solutions (low-cost)}

Another response to wicked water problems, and the above risk of political deadlock, is to embrace the idea of clumsy solutions, a term coined by Michael Shapiro (1988) as a way to allow for many contradictory goals to be pursued simultaneously, without the need for concrete definitions of problems and solutions (a key challenge in wicked problems). Clumsiness is thus the opposite of elegance or optimality in policy making, and demands instead that multiple values, frameworks, and voices be harnessed simultaneously "clumsily, [and] contradictorily" (Hulme 2009:338). Clumsiness is the acceptance that although natural science seeks to define problems and solutions clearly within a 
Fig. 1. The water governance solutionscape of science-policy-practice-participation.

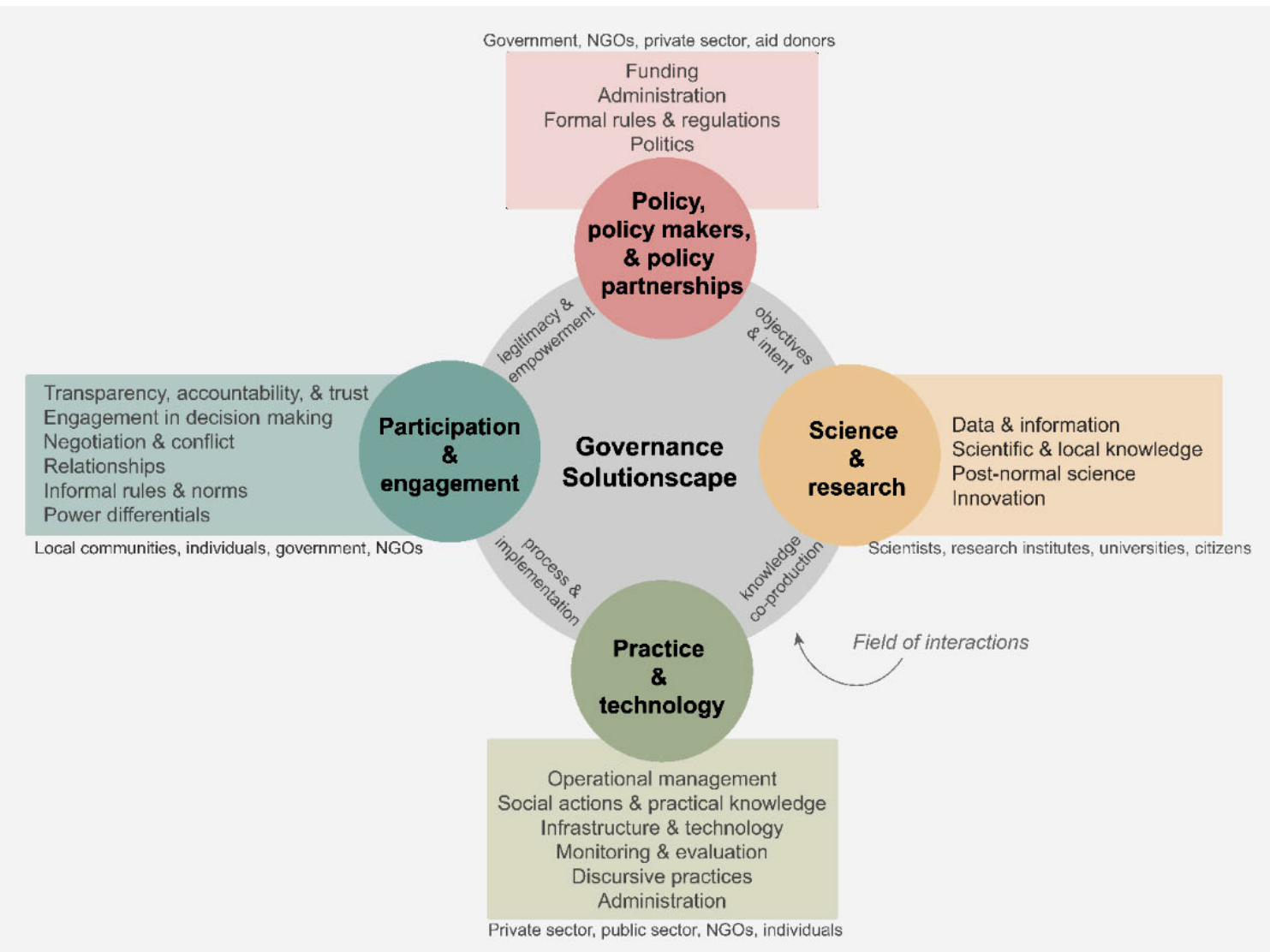

unitary framework, social systems resist such resolute frameworks (Hulme 2009). Clumsy solutions are not perfect; a key risk is thus that sub-optimal solutions might lead to sub-optimal outcomes. Further, with many different moving parts working at different temporal and spatial scales, the effectiveness of clumsy solutions is difficult to measure because they will not be targeting the same collective problem. This may even lead to them cancelling each other out. For example, raising irrigation efficiency may increase consumption, resulting in little change to the overall sustainability of the resource (Grafton et al. 2018). However, the appeal of clumsy solutions is the lower financial (and perhaps political) costs required in comparison to comprehensive solutions, and the potential for "buying time" until a more comprehensive solution is developed. This is visualized as balanced, yet separated, spheres in Figure 2.

\section{Expedient solutions (high-cost)}

Expedient solutions are those in which two or three dimensions of the solutionscape are focused on to fast-track progress on the most important features of the problem at hand. The "high-cost" version of this may be technocratic top-down implementation of technology, without much consultation with local communities (which may speed up implementation but put durability at risk). Such approaches of course raise some ethical questions, and may reflect the interests or beliefs of the most powerful stakeholders in the given context, and a "we know best" attitude.

\section{Expedient solutions (low-cost)}

Low-cost versions of expedient solutions also exist, for example, in developing countries where institutional capacity and financial resources may be limited, but there is scientific agreement at the local level combined with engagement with the local community. Formal services may still be limited, but the slow pace of change delivered by government may be circumnavigated if the institutions involved are inclusive and well-resourced. Expedient solutions also aim to provide faster relief from serious day-to-day challenges faced by communities, who cannot wait for assistance with issues such as conflict management between water users, or water access. This can be seen, for example, through the work of NGOs in developing countries in building wells for community water access in response to inadequate infrastructure and insufficient resources available at a national-level to fix this.

Lankford et al. (2007) argue that an expedient form of water resources management is particularly advisable in developing countries (where resources are limited), focusing on practical rather than principled grounds, and on problem identification and solution rather than adopting certain norms (e.g., IWRM). In an example from southern Tanzania, Lankford et al. (Lankford 2001, Lankford et al. 2007) argue that concentrating on irrigation abstractions from only a few rivers (rather than all rivers) flowing into the Usangu wetland is a more strategically efficient intervention to restore its hydrology and health. Low-cost 
Fig. 2. Six governance solutionscape expressions for responding to wicked water problems.

\section{4 balanced solutions}

Comprehensive (high-cost)

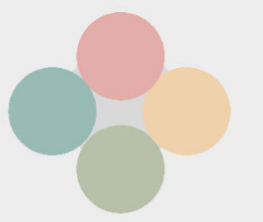

Clumsy (low-cost)

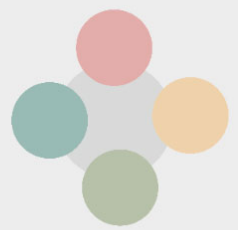

2-3 selective solutions

Expedient (high-cost)

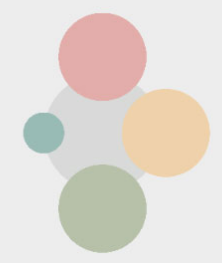

Expedient (low-cost)

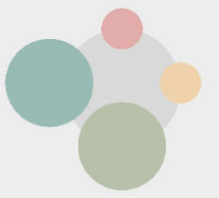

\section{$0-1$ solutions}

\author{
Solutionism
}

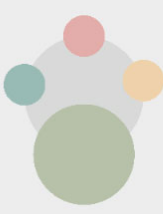

Anti-solution

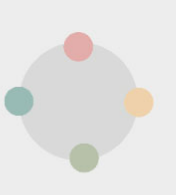

Policy, policy makers \& partnerships

Science \& research

Participation

\& engagement

Practice \& technology

Interactions expedient solutions might also originate in "fintech" technologies, such as mobile water payments in Africa (Hope et al. 2012). Such approaches, however, may run the risk of undermining longer term change planned at a higher level, such as schemes that increase livelihood diversification, but are conflicting with national plans for poverty reduction.

\section{Solutionism}

Seen in the top middle of Figure 2, solutionism is an overemphasis on (usually) one solutionscape dimension. Solutionism was first used in the field of urban planning and architecture to describe a naïve faith in the benign nature of technology, neglecting any type of reckoning with consciousness (Murphy 2012). Morozov (2013) describes solutionism in technology as the ideology that legitimizes and sanctions actions that presume rather than investigate the problems they attempt to solve. It is the idea that every social problem has a technological fix. Solutionism reaches for the answer before the right questions are asked; however, often what solutionists presume to be problems, such as inefficiency and ambiguity, may not be problems at all (Morozov 2013). Morozov argues that through attempts to make life trouble-free with technology, solutionism drives out imperfections. However, in doing so, it also shuts out other markers of success, such as goals rooted in justice, ethics, and philosophy.

Solutionism therefore reminds us to critically examine quick or reflex fixes taken toward wicked problems. For example, Hulme (2009) alludes to the risk of technological fixes in the climate change problem, calling for greater consideration of the Pandora's box that emerges from geo-engineering the climate, a venture described by Lie (2007) as the "colonization of nature." However, it is not just through technology that uncritical thinking is applied; indeed, there is evidence of poorly articulated development projects with depoliticized "check-box thinking" with regards to community participation, and of fast-tracked policy decisions that seek to quickly rectify decades of institutional issues, such as those seen in South Africa and Zimbabwe's fast-tracked IWRM-based water sector reforms (Leal 2010, Mtisi and Nicol 2015). By recasting complex situations as neatly defined problems with definite solutions, or as transparent and self-evident processes that can be easily optimized may result in unexpected consequences. These could "cause more damage that the problems they seek to address" (Morozov 2013:5).

We therefore propose a typology of solutionism as applicable to the governance of water and related natural resources, in the solving of wicked water problems. Solutionism has three core defining features, as shown in Box 1.

\section{Box 1: Defining features of solutionism}

1. The problem to be solved is presumed or created, rather than investigated thoroughly; the answer is sought before the right questions are asked.

2. The problem is neatly defined with definite solutions that focus on efficiency and the need to drive out imperfection; markers of success are narrowly defined, with little consideration of ethical and philosophical markers.

3. The solution does not solve broader social or political problems, and may lead to unintended consequences.

(Adapted from Morozov 2013)

Solutionism may occur when any of the four dimensions of the solutionscape is overemphasized. For example, it may be witnessed in situations where policy makers look to scientists for clear-cut answers to complex problems, rather than for a range of 
scenarios and solutions. The risk here is that science alone cannot solve societal issues, and the simplification of wicked problems means other perspectives are not considered. Such pressure on scientists can also lead to a perpetual goal of reducing uncertainty in their research (e.g., more knowledge), while this is often not the key issue.

The scientific and political stalemate that can occur because of the complexity, uncertainty, and divergence of wicked problems may lead proponents of simple solutions to claim they can circumnavigate slow, hierarchical institutions. Outside of bureaucratic institutions, solutions can be implemented faster and without administrative red-tape. However, this does not come without its own challenges, such as a disregard for long-term reshaping of institutions, potentially masking the issue with shortterm solutions. Yet, as Head (2010:102) states: "modern society is too pluralistic to tolerate [such] imposed and artificial solutions." Further, there is a risk of autocratic governance regimes taking hold, with solutionist ends warranting the means. For example, this could be seen in strict carbon reduction policies (in efforts to reach greenhouse gas emissions targets) that may increase inequality. Elite capture of water resources by the most powerful actors in the guise of efficiency and benefit-optimization (Boelens and Vos 2012) can create a similar ethical dilemma, for example, by industry taking the lead in water resources management in a socially complex river basin. However, elite capture may not necessarily be damaging, and depends on how leadership roles are utilized.

\section{Anti-solutions}

Although the previous four solutions involve differing levels of support and integration of the four governance solutionscape dimensions, what we term anti-solutions may completely dismantle or undermine one or more dimensions, or deny the existence of the problem altogether. For example, an authoritarian government may deny local social impacts of hydropower dams, e.g., as seen in places along the Mekong, or limit participation in decision-making processes to reduce obstructions to economic development plans. As suggested by Frickel and Rea (2020), this may also occur through the dismissal of scientific evidence in policy agendas, e.g., anthropogenic climate change. However, such strong responses to scientific evidence are not only facilitated by particular (undemocratic) political structures, but also through ideologies and power, which may manifest even within democratic society. Summarizing the above, Table 1 details the six solution expressions as they relate to the four dimensions of the governance solutionscape.

\section{APPLYING THE SOLUTIONSCAPE TO THE DORINGLAAGTE}

We now illustrate how the solutionscape framework can be utilized, using the South African Doringlaagte case study as an illustrative example. We first consider the four dimensions in the case study, along with the main actors in each. The key elements of this can be seen in Table 2 (see Appendix 1 for a more detailed description).

First, considering the science and research dimension, there has historically been high uncertainty regarding the aquifer's physical status, though this is slowly improving because of recent hydrogeological modeling (Ebrahim et al. 2019). However, data scarcity remains; long-term groundwater level observations are limited because of a degraded monitoring network, as are some issues of data sharing because of distrust between commercial farmers and the government.

The area's policy issues relate largely to the implementation failures of South Africa's National Water Act, and weak water license regulation. This is compounded by high staff turnover rates in the regional DWS, which undermined relationshipbuilding between the farming community and government. Failures to establish a WUA have further undermined these relationships.

In the Doringlaagte, there is an apparent divide between the policy environment in theory, and the messy reality in practice. Because of weak formal water management, groundwater management practices primarily occur within socially embedded institutions of the farming community. Practical knowledge of the resource is high amongst commercial farmers, who rely on both scientific information (e.g., short-term weather reports) and traditional knowledge (e.g., using anthills to predict rainfall). This interesting mixture of practices is potentially shifting, however, because of an emerging younger generation of more highly educated farmers. Nevertheless, current daily practices around water management are persistent, and influenced by discursive practices related to how farmers perceive their water issues.

Finally, as shown in Table 2, equitable participation and engagement is relatively weak in the Doringlaagte because of historical racial divides between emerging and commercial farmers. This has not only led to unequal land tenure, and therefore groundwater access, but also unequal participation in water management activities; emerging farmers, i.e., previously disadvantaged subsistence/smallholder farmers transitioning toward commercializing their produce, interviewed in the area were unaware of the local agricultural union.

\section{Solutionscape expression in the Doringlaagte}

Our use of the solutionscape framework suggests that with respect to the Doringlaagte aquifer, the four governance spheres are not in balance; we believe that practice and technology is the dominating (solutionist) dimension because of legacy effects of irrigated farming in the area. As per solutionism, the water problem of the study area is largely presumed to be a technical one (ignoring issues of equity and livelihoods), with the solution therefore focusing on water-use efficiency without considering broader social or political problems.

We found that historical legacies and elite capture still unconsciously dictate how groundwater is governed in the Doringlaagte, with minimal influence from the policy, practice, and science spheres, and conceivably a lack of an honest broker to expand the solutionscape beyond solutionism. This imbalance is portrayed in Figure 3.

As shown in Fig. 3, the science sphere is small because of data limitations. However, recent modeling efforts may go a long way in altering practices currently undertaken in the catchment (thus increasing the size of the conceptual science and research sphere). For example, boundary work is increasing, with local researchers supporting some interaction and data-sharing between DWS and farmers. However, scientific information's utility in groundwater 
Table 1. Key features of the 'solutionscape' and its expressions.

\begin{tabular}{|c|c|c|c|c|c|c|}
\hline & \multicolumn{6}{|c|}{ Solutionscape expression } \\
\hline & Anti-solution & $\begin{array}{l}\text { Expedient } \\
\text { solution } \\
\text { (low-cost) } \\
\end{array}$ & $\begin{array}{l}\text { Expedient solution } \\
\text { (high-cost) }\end{array}$ & Solutionism & $\begin{array}{l}\text { Clumsy solution } \\
\text { (low-cost) }\end{array}$ & $\begin{array}{l}\text { Comprehensive } \\
\text { solution (high- } \\
\text { cost) }\end{array}$ \\
\hline Description & $\begin{array}{l}\text { One or more } \\
\text { dimensions of } \\
\text { governance } \\
\text { actively } \\
\text { disregarded or } \\
\text { attacked by } \\
\text { policy sphere; } \\
\text { problem possibly } \\
\text { denied. }\end{array}$ & $\begin{array}{l}\text { Two or three } \\
\text { dimensions of } \\
\text { governance } \\
\text { supported and } \\
\text { fast-tracked; } \\
\text { focus usually on } \\
\text { local-level } \\
\text { problem-solving; } \\
\text { low-cost. }\end{array}$ & $\begin{array}{l}\text { Two or three } \\
\text { dimensions of } \\
\text { governance } \\
\text { supported and fast- } \\
\text { tracked: usually } \\
\text { top-down (e.g., } \\
\text { downscaling/ } \\
\text { distribution of new } \\
\text { technology); high } \\
\text { cost. }\end{array}$ & $\begin{array}{l}\text { Focus on one } \\
\text { dimension of } \\
\text { governance; } \\
\text { poorly defined } \\
\text { problem; rushed; } \\
\text { lowest-cost } \\
\text { option, often } \\
\text { outside of policy } \\
\text { sphere. }\end{array}$ & $\begin{array}{l}\text { Separate } \\
\text { responses } \\
\text { pursued, but } \\
\text { uncoordinated; } \\
\text { poorly defined } \\
\text { problem; cheap } \\
\text { to implement. }\end{array}$ & $\begin{array}{l}\text { All dimensions of } \\
\text { governance } \\
\text { supported and } \\
\text { connected; } \\
\text { collaborative; well- } \\
\text { defined problem; } \\
\text { typically, high } \\
\text { transaction costs. }\end{array}$ \\
\hline $\begin{array}{l}\text { Science and } \\
\text { research }\end{array}$ & $\begin{array}{l}\text { Scientific } \\
\text { research } \\
\text { deliberately } \\
\text { ignored/denied. }\end{array}$ & $\begin{array}{l}\text { Research } \\
\text { detached from } \\
\text { formal decision } \\
\text { making, focused } \\
\text { on local level. }\end{array}$ & $\begin{array}{l}\text { Research may be } \\
\text { highly technical } \\
\text { and connected to } \\
\text { higher levels of } \\
\text { decision making, } \\
\text { without much } \\
\text { feedback at a local } \\
\text { level. }\end{array}$ & $\begin{array}{l}\text { Shallow } \\
\text { understanding } \\
\text { of problem; } \\
\text { solutionist if } \\
\text { overfocus on } \\
\text { linear knowledge } \\
\text { transfer. }\end{array}$ & $\begin{array}{l}\text { Adequate (in } \\
\text { one or more } \\
\text { fields), but } \\
\text { poorly } \\
\text { communicated. }\end{array}$ & $\begin{array}{l}\text { Comprehensive in } \\
\text { all fields; } \\
\text { knowledge co- } \\
\text { production; post- } \\
\text { normal science; } \\
\text { holistic. }\end{array}$ \\
\hline $\begin{array}{l}\text { Policy and } \\
\text { partnerships }\end{array}$ & $\begin{array}{l}\text { Support for anti- } \\
\text { environmental } \\
\text { policies; focus } \\
\text { on economic } \\
\text { partnerships; } \\
\text { vast power } \\
\text { asymmetries. }\end{array}$ & $\begin{array}{l}\text { Weak/slow policy } \\
\text { implementation; } \\
\text { uncoordinated } \\
\text { partnerships. }\end{array}$ & $\begin{array}{l}\text { Fast-tracked } \\
\text { policies and } \\
\text { working within } \\
\text { existing } \\
\text { partnerships. }\end{array}$ & $\begin{array}{l}\text { Risk of over- } \\
\text { focus on policy } \\
\text { change instead } \\
\text { of focusing on } \\
\text { implementation; } \\
\text { most powerful } \\
\text { player } \\
\text { dominates. }\end{array}$ & $\begin{array}{l}\text { Loose network } \\
\text { of players and } \\
\text { partners; policy } \\
\text { may be broad } \\
\text { but } \\
\text { inappropriate to } \\
\text { context. }\end{array}$ & $\begin{array}{l}\text { Policy is } \\
\text { appropriate to } \\
\text { context; least } \\
\text { powerful players } \\
\text { empowered. }\end{array}$ \\
\hline $\begin{array}{l}\text { Practice and } \\
\text { technology }\end{array}$ & $\begin{array}{l}\text { Technology } \\
\text { supported where } \\
\text { leads to } \\
\text { economic } \\
\text { growth. }\end{array}$ & $\begin{array}{l}\text { Focus on delivery } \\
\text { at local level } \\
\text { outside of policy } \\
\text { sphere; efficient. }\end{array}$ & $\begin{array}{l}\text { Focus usually } \\
\text { emphasized here (e. } \\
\text { g., development of } \\
\text { new technology to } \\
\text { be disseminated). }\end{array}$ & $\begin{array}{l}\text { Risk of } \\
\text { overfocus on } \\
\text { technological } \\
\text { fixes and hard } \\
\text { engineering } \\
\text { responses } \\
\text { without } \\
\text { recognition of } \\
\text { social or } \\
\text { political context/ } \\
\text { needs. }\end{array}$ & $\begin{array}{l}\text { Well-supported } \\
\text { but independent } \\
\text { from other types } \\
\text { of knowledge (e. } \\
\text { g., local/ } \\
\text { indigenous } \\
\text { knowledge). }\end{array}$ & $\begin{array}{l}\text { Appropriate use of } \\
\text { technology; policy } \\
\text { implemented. }\end{array}$ \\
\hline $\begin{array}{l}\text { Participation } \\
\text { and } \\
\text { communication }\end{array}$ & $\begin{array}{l}\text { Blocked } \\
\text { participation of } \\
\text { scientific } \\
\text { community; } \\
\text { processes not } \\
\text { transparent. }\end{array}$ & $\begin{array}{l}\text { Active } \\
\text { engagement but } \\
\text { in need of } \\
\text { boundary } \\
\text { organization to } \\
\text { mediate. } \\
\text { Participation used } \\
\text { for empowerment } \\
\text { and social } \\
\text { transformation } \\
\text { (bottom-up). }\end{array}$ & $\begin{array}{l}\text { Usually limited } \\
\text { participation at } \\
\text { local-level, } \\
\text { decisions imposed } \\
\text { from above. } \\
\text { Participation } \\
\text { instrumental for } \\
\text { efficiency, rather } \\
\text { than } \\
\text { empowerment. }\end{array}$ & $\begin{array}{l}\text { Participation } \\
\text { used as } \\
\text { instrument of } \\
\text { efficiency and/or } \\
\text { display of } \\
\text { inclusion. Focus } \\
\text { on } \\
\text { decentralization. } \\
\text { Risk of } \\
\text { overfocus on } \\
\text { participatory } \\
\text { processes as a } \\
\text { quick-fix. }\end{array}$ & $\begin{array}{l}\text { Communication } \\
\text { weak and in } \\
\text { need of } \\
\text { boundary } \\
\text { organization/ } \\
\text { coordination; } \\
\text { self-governing. }\end{array}$ & $\begin{array}{l}\text { Inclusive and } \\
\text { appropriate } \\
\text { participation; } \\
\text { coordinated } \\
\text { communication via } \\
\text { boundary } \\
\text { organizations; co- } \\
\text { governing } \\
\text { collaboration. } \\
\text { Goal of } \\
\text { empowerment and/ } \\
\text { or representation. }\end{array}$ \\
\hline
\end{tabular}




\begin{tabular}{|c|c|c|c|c|c|c|}
\hline $\begin{array}{l}\text { Knowledge } \\
\text { and data } \\
\text { flows }\end{array}$ & $\begin{array}{l}\text { Poor scientific } \\
\text { literacy in } \\
\text { decision-making } \\
\text { sphere. }\end{array}$ & $\begin{array}{l}\text { Fragmented, } \\
\text { informal but well- } \\
\text { informed, post- } \\
\text { normal } \\
\text { understandings. }\end{array}$ & $\begin{array}{l}\text { Fragmented and } \\
\text { focused on } \\
\text { technical/risk- } \\
\text { based framings. }\end{array}$ & $\begin{array}{l}\text { One type of } \\
\text { knowledge } \\
\text { focused on ("we- } \\
\text { know-best" } \\
\text { attitude). }\end{array}$ & $\begin{array}{l}\text { Varying } \\
\text { perspectives and } \\
\text { knowledge types. } \\
\text { Some ad hoc } \\
\text { information } \\
\text { sharing. }\end{array}$ & $\begin{array}{l}\text { Post-normal } \\
\text { science; } \\
\text { coordinated; } \\
\text { multiple } \\
\text { knowledge types. }\end{array}$ \\
\hline $\begin{array}{l}\text { Symptoms vs } \\
\text { causes }\end{array}$ & $\begin{array}{l}\text { Complete denial } \\
\text { of existence of } \\
\text { problems. }\end{array}$ & $\begin{array}{l}\text { Targeting causes } \\
\text { of problems, } \\
\text { usually focusing } \\
\text { on community } \\
\text { needs and deep- } \\
\text { rooted issues (e.g., } \\
\text { community } \\
\text { conflicts over } \\
\text { water). }\end{array}$ & $\begin{array}{l}\text { Can be targeting } \\
\text { either symptoms or } \\
\text { causes, focusing on } \\
\text { what is deemed the } \\
\text { issue at a high-level } \\
\text { by decision makers. }\end{array}$ & $\begin{array}{l}\text { Treats symptoms } \\
\text { without getting } \\
\text { to cause of } \\
\text { problem; } \\
\text { oversimplification } \\
\text { and focus on } \\
\text { appearing } \\
\text { effective over } \\
\text { being effective. }\end{array}$ & $\begin{array}{l}\text { Treats symptoms } \\
\text { independently } \\
\text { ("putting out } \\
\text { fires"). }\end{array}$ & $\begin{array}{l}\text { Concentrates on } \\
\text { underlying causes } \\
\text { of problems. }\end{array}$ \\
\hline $\begin{array}{l}\text { Capacity and } \\
\text { resources }\end{array}$ & $\begin{array}{l}\text { Resources } \\
\text { available but } \\
\text { politically } \\
\text { blocked. }\end{array}$ & $\begin{array}{l}\text { Weak capacity/ } \\
\text { supporting } \\
\text { financial and } \\
\text { human resources. }\end{array}$ & $\begin{array}{l}\text { High cost and } \\
\text { required resources } \\
\text { (financial and } \\
\text { technical needs } \\
\text { high). }\end{array}$ & $\begin{array}{l}\text { Resources } \\
\text { limited to one } \\
\text { governance } \\
\text { dimension } \\
\text { (resulting in } \\
\text { resource } \\
\text { constraints in } \\
\text { other } \\
\text { dimensions). }\end{array}$ & $\begin{array}{l}\text { Funding project- } \\
\text { by-project (not } \\
\text { coordinated). }\end{array}$ & $\begin{array}{l}\text { High transaction } \\
\text { costs and resources } \\
\text { requirements } \\
\text { because of } \\
\text { significant } \\
\text { coordination } \\
\text { between } \\
\text { governance } \\
\text { dimensions. }\end{array}$ \\
\hline $\begin{array}{l}\text { Embeddedness } \\
\text { with other } \\
\text { issues and } \\
\text { context }\end{array}$ & $\begin{array}{l}\text { Perspectives } \\
\text { determined by } \\
\text { political and } \\
\text { economic } \\
\text { context. }\end{array}$ & $\begin{array}{l}\text { Embedded in } \\
\text { local context, } \\
\text { bottom-up } \\
\text { response. }\end{array}$ & $\begin{array}{l}\text { Can be embedded } \\
\text { with other issues, } \\
\text { but typically top- } \\
\text { down "we know } \\
\text { best" approach. }\end{array}$ & $\begin{array}{l}\text { Poor } \\
\text { acknowledgement } \\
\text { of social context } \\
\text { or intersecting } \\
\text { problems. }\end{array}$ & $\begin{array}{l}\text { Shallow } \\
\text { understanding } \\
\text { of context and } \\
\text { intersecting } \\
\text { problems. }\end{array}$ & $\begin{array}{l}\text { Understanding of } \\
\text { context and } \\
\text { intersecting issues. }\end{array}$ \\
\hline
\end{tabular}

management strategies remains undermined by factors such as distrust between farmers and government, and the salience of information shared (Fallon et al. 2019). Data gaps have also allowed alternative narratives to form, such as (unverified) illegal dams in the catchment.

Meanwhile, the policy sphere is ill-fitted to the specific contextual realities in practice, as seen elsewhere in South Africa's attempts to implement post-apartheid water policies (Schreiner 2013, Förster et al. 2017). We found in the Doringlaagte that some smallholder farmers were concerned that improved licensing regulation would damage their livelihoods; because of administrative illiteracy around water licenses, some had not paid licensing fees and water-use charges in the past, and were therefore concerned they had large debts (even if this was not the case). Such administrative misunderstandings have also been described elsewhere in South Africa (van Koppen and Schreiner 2014). Meanwhile, commercial farmers remain highly literate in South Africa's water policy.

This irony has played out elsewhere in South Africa in a number of instances; for example, water has been allocated to emerging farmers in the Mpumalanga Province for the irrigation of 800 hectares of land, and yet they did not have access to land to make use of their water allocation. Similarly, emerging farmers in the Western Cape accessed land in the Breede water management area as part of the land reform program, yet access to water entailed the development of infrastructure that was beyond the financial means of the community (Weston, 2019, personal communication).
This indicates that South Africa's water (and land) policies do not fit the needs or realities on the ground, and may perpetuate existing practices rather than achieve progressive policy goals.

Conversely, equity and collaboration goals within South Africa's water policies are undermined by longstanding historical legacies within the practice sphere and an unsupported participation sphere. The political context in South Africa is one of discrimination through the irrigation boards (under previous legislation), which still ostensibly exist as a result of poor policy decision making (e.g., see Förster et al. 2017). Those serving on the apartheid-era irrigation boards have inevitably ended up in newer WUAs (or related institutions), with often little participation from emerging or smallholder farmers. As discussed earlier, this is reflected in the Doringlaagte area, where emerging farmers are not involved in the agricultural union, and existing practices continue.

This framing also suggests an incomplete characterization of the study area's water issues, with most appraisals focused on the physical sustainability of the aquifer supporting commercial farming, without questioning (a) whether or not this is the most optimal use of water in a semi-arid environment; (b) what the best approach to developing the local social economy would be; and (c) why water access for marginalized people living in the area remains limited. This ignores the potential of participatory processes to be used as part of a wider political project aimed at citizen rights and participation of marginalized groups (e.g., Hickey and Mohan 2004). By reducing the scope of the question, 
Table 2. Key elements of the Doringlaagte Basin through the solutionscape.

\begin{tabular}{|c|c|c|c|}
\hline Dimension & Elements & Case examples & Key actors \\
\hline Science and research & Data and information & $\begin{array}{l}\text { Low data/high uncertainty re: long- } \\
\text { term groundwater trends. } \\
\text { Groundwater monitoring at farm-level. }\end{array}$ & $\begin{array}{l}\text { Research Institutes, e.g., International } \\
\text { Water Management Institute (IWMI), } \\
\text { Water Research Commission, } \\
\text { Department of Water and Sanitation } \\
\text { (DWS), commercial farmers, local } \\
\text { borehole manager. }\end{array}$ \\
\hline \multirow[t]{4}{*}{$\begin{array}{l}\text { Policy, policy makers, } \\
\text { and partnerships }\end{array}$} & $\begin{array}{l}\text { Funding and } \\
\text { administration }\end{array}$ & $\begin{array}{l}\text { Lack of funding for monitoring } \\
\text { networks and regulation. }\end{array}$ & Provincial and National DWS. \\
\hline & Formal rules and & Ill-fit between policy and local context. & National DWS. \\
\hline & regulations & $\begin{array}{l}\text { Poor regulation of water licenses and } \\
\text { implementation of water policies. }\end{array}$ & Provincial DWS (Polokwane). \\
\hline & Politics & $\begin{array}{l}\text { High staff turnover rate. } \\
\text { Low sectoral coordination. }\end{array}$ & $\begin{array}{l}\text { DWS, related government branches, e. } \\
\text { g., Limpopo Provincial Dept. } \\
\text { Agriculture and Rural Development. }\end{array}$ \\
\hline \multirow[t]{5}{*}{$\begin{array}{l}\text { Practice and } \\
\text { technology }\end{array}$} & $\begin{array}{l}\text { Operational } \\
\text { management }\end{array}$ & $\begin{array}{l}\text { Day-to-day operations (groundwater } \\
\text { pumping, center-pivot irrigation). }\end{array}$ & $\begin{array}{l}\text { Commercial farmers, emerging farmers, } \\
\text { local borehole manager. }\end{array}$ \\
\hline & $\begin{array}{l}\text { Administration, } \\
\text { infrastructure, and } \\
\text { technology }\end{array}$ & $\begin{array}{l}\text { Water licensing admin. and monitoring } \\
\text { boreholes. }\end{array}$ & DWS, farmers. \\
\hline & $\begin{array}{l}\text { Routinized social } \\
\text { practices }\end{array}$ & $\begin{array}{l}\text { Water management strategies, e.g., } \\
\text { night-time irrigation. } \\
\text { Individual farm management. }\end{array}$ & $\begin{array}{l}\text { Commercial farmers, smallholder } \\
\text { farmers. }\end{array}$ \\
\hline & Practical knowledge & $\begin{array}{l}\text { Practical knowledge of natural } \\
\text { environment and aquifer dynamics. }\end{array}$ & Commercial farmers. \\
\hline & Discursive practices & $\begin{array}{l}\text { Farmer communication re: } \\
\text { groundwater depletion (e.g., tragedy of } \\
\text { the commons), changing climate, and } \\
\text { government relationships. }\end{array}$ & Commercial farmers, DWS. \\
\hline \multirow[t]{4}{*}{$\begin{array}{l}\text { Participation and } \\
\text { engagement }\end{array}$} & $\begin{array}{l}\text { Transparency, } \\
\text { accountability, and } \\
\text { trust }\end{array}$ & $\begin{array}{l}\text { Low trust between government and } \\
\text { farming community. } \\
\text { Low trust in SAWS forecasts. } \\
\text { Building trust between some individual } \\
\text { hydrogeologists (DWS) and farmers. }\end{array}$ & $\begin{array}{l}\text { Commercial farmers, Provincial DWS, } \\
\text { SAWS. }\end{array}$ \\
\hline & $\begin{array}{l}\text { Engagement in } \\
\text { decision making }\end{array}$ & $\begin{array}{l}\text { Little to no participation of black } \\
\text { emerging farmers in Agri Union. }\end{array}$ & $\begin{array}{l}\text { Commercial and smallholder } \\
\text { (emerging) farmers. }\end{array}$ \\
\hline & $\begin{array}{l}\text { Power differentials } \\
\text { (gender, class, wealth) }\end{array}$ & $\begin{array}{l}\text { Wealth and land tenure divides between } \\
\text { white and black farmers. } \\
\text { Commercial farmers predominantly } \\
\text { male. }\end{array}$ & $\begin{array}{l}\text { Commercial and smallholder } \\
\text { (emerging) farmers. }\end{array}$ \\
\hline & $\begin{array}{l}\text { Informal rules and } \\
\text { norms, relationships }\end{array}$ & $\begin{array}{l}\text { Water user association not approved } \\
\text { (agricultural union formed instead); } \\
\text { some informal management. }\end{array}$ & $\begin{array}{l}\text { Pietersburg Agricultural Union, } \\
\text { commercial farmers. }\end{array}$ \\
\hline
\end{tabular}

the solution was predetermined as a technical one, and not one also of social justice. Social issues also affect commercial farmers, who have maintained livelihoods in the area for many years with little (perceived) government support regarding livelihood diversification or subsidies for providing food security to the region, e.g., switching to less water-intensive crops. An incomplete understanding of the catchment's water issues has also had unanticipated effects, such as (so far unsubstantiated) allegations that some wealthy farmers are buying up land in the west of the catchment, where land is mainly owned by black communities and thus not yet extensively farmed. Such claims may exacerbate a "tragedy of the commons" narrative (Hardin 1968) held by some farmers, whereby users are viewed to be in a race-to-the-bottom for natural resources.

It is possible that the Doringlaagte's solutionscape expression may shift, particularly as scientific research increases in the area and more boundary work broadens participation. However, without dealing with related issues across South Africa (such as land tenure and agricultural policy), implementation of its water policies and strategies will remain limited. It is therefore conceivable that through discussion of different future scenarios, the solutionscape could shift from one of solutionism to a low- 
Fig. 3. Solutionscape expression in the Doringlaagte case study. NWA = National Water Act; WUA = water user associations.

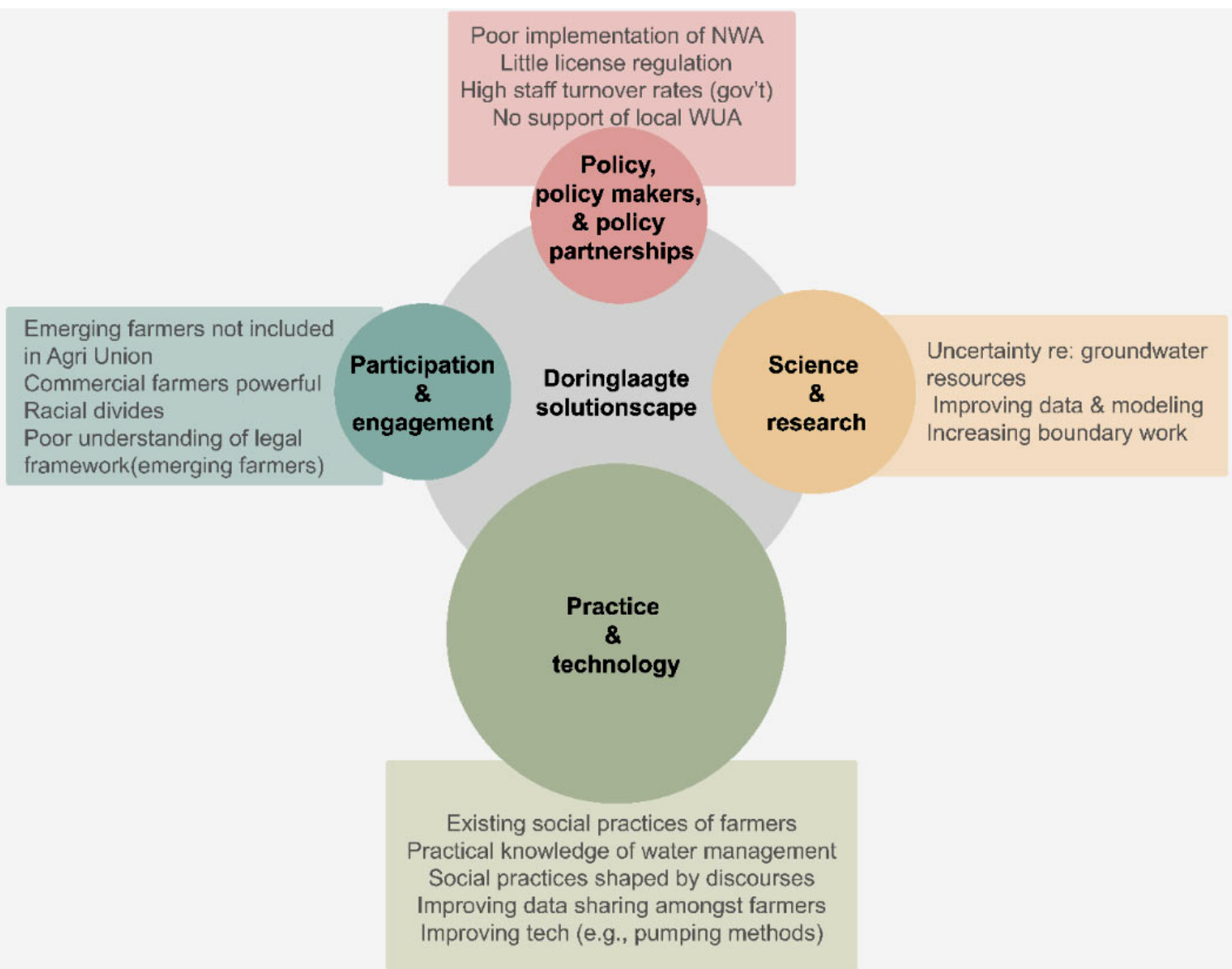

cost expedient solution. This could move existing practices toward more sustainable groundwater use, while circumventing institutional stalemates.

\section{DISCUSSION}

We have conceived water governance as a dynamic field, or solutionscape, of interactions between four dimensions of science, policy, participation, and practice, each representing an epistemic community and the associated activities underpinning how water is managed. Within this solutionscape, six broad solution-types emerge and express themselves, depending on how these four dimensions are emphasized or balanced. The solutionscape can be seen as a reflective space within which solutions are (or fail to be) renegotiated and reshaped by interacting stakeholders. It is a space of ongoing contestation, reaching for the answers of problems that themselves are constantly changing. Because of the inability to identify a clear root cause of wicked water problems, every solution is likely to be contested and insufficient to some extent (Head 2010). This is not to say that all six solution-types are completely inadequate; an expedient solution can fast-track progress around institutional barriers and improve human well-being, and a clumsy solution can still enable progress from multiple angles despite coordination difficulties. In some instances, such solution-types can become a useful and catalytic step toward realizing a more comprehensive solution.

This framing also places epistemic communities (and their activities) at the heart of water governance, which is often missing. Epistemic communities play an important role under conditions of complexity and uncertainty by providing knowledge across disciplines to articulate a better understanding of the problem and its potential solutions (Haas 1992) across the blurred boundary between science and policy (Guston 2001, Hoppe and Wesselink 2014, Gustafsson and Lidskog 2018). However, more often it is a space where habituated interventions are automatically favored, steered by the most powerful actors (as seen in the South African case). The six expressions presented in Figure 2 are therefore not end-points, nor necessarily conflicting with one another; rather, they show the ways in which people, technology, and resources ally together (or do not) in response to wicked water problems.

It is in this sense that the proposed solutionscape may help us discern what, or who, drives or hinders transformative change and for what agenda, a process that is too often implicit or automatic. For example, it is important that scientists are clear on their (actual and desired) role and influence in policy making, 
and more inclusive of perspectives outside the positivist paradigm (Pielke 2007, Meissner 2016a). Likewise, policy makers need to be aware of the social realities on the ground when designing and implementing water policies, and practitioners of the discursive practices subconsciously shaping their views and activities. More attention should therefore be paid to honest brokering in expanding the scope of decision-making choices, and facilitating collaboration between stakeholders with varying views (Pielke 2007).

As a heuristic tool, the solutionscape could be used for other wicked water problems to discuss their governance arrangements. However, it is limited in its analytical capabilities, and thus should be approached primarily as an exploratory framework. It may also, in reality, be difficult (and partially subjective) to discern which solution-type is dominant in a particular setting. However, we feel the solutionscape has potential in revealing how wicked problems are governed beyond what is seen on the surface, e.g., by bringing informal institutions and politics into focus, and highlights the dynamic nature of wicked problems and their solutions. We would therefore be interested in seeing this heuristic device utilized for other case studies and solution types, particularly in comparison to more conventional governance tools.

\section{CONCLUSIONS}

Wicked water problems are difficult, and even impossible, to solve because of their inherent complexity, uncertainty, and diversity of perspectives. To better comprehend wicked water problems and their possible solutions, we have thus developed a solutionscape within which four key dimensions interact: science, policy, practice, and participation. This leads to one of six broad outcomes: comprehensive, clumsy, expedient (high and low cost), solutionist, or anti-solutions. In an ideal situation, the four dimensions of the solutionscape would be comprehensive and balanced, though there are certain benefits found in clumsy and expedient solutions in attempting to address wicked problems. Although limitations exist, such as difficulties in identifying interventions that might be a hybrid of solutions, the solutionscape may provide a basis for the disentanglement of approaches to wicked water problems.

We briefly illustrated this conceptualization with the case of the Doringlaagte, a small aquifer located in the Hout Catchment of the Limpopo River Basin in South Africa, which is experiencing extensive groundwater irrigation for agriculture. We found that existing practices, shaped by historical legacies of water access and control, endure because of scientific uncertainty around the aquifer's behavior and depletion rates, weak policy implementation, and inequitable participation in decisionmaking processes. We believe this is leading to a solutionist approach to the area's water problems, where pre-existing practices dominate how groundwater was and is managed, and where the problem itself is defined primarily as technical, without fully considering broader socio-political issues inherent across South Africa's water sector.

The solutionscape suggests that governing wicked water problems is less about seeking optimization to a preferred single outcome (as is often the focus of governance studies), and more about asking stakeholders to map out their contestations and deliberations. This may enable them to develop a transdisciplinary, collaborative process that links science, policy, practice, and participation equally. The solutionscape is thus primarily a tool for reflecting more transparently upon the different ways in which we perceive, interact with, and address wicked water problems. This requires a certain level of honesty and humility amongst stakeholders regarding their own agendas, biases, and influence on decision-making processes, and more critical participation that opens up rather than shuts down debate. Noting the complexity of this task, the identification, role, and support of honest solutionscape brokers could be essential to navigating the four dimensions of science, policy, practice, and participation and their interconnections. In doing so, a plurality of perspectives and knowledge-types may be drawn upon to reimagine how and why we govern wicked water problems.

Responses to this article can be read online at: https://www.ecologyandsociety.org/issues/responses. php/12504

\section{Acknowledgments:}

The authors are grateful to the anonymous reviewers for their insightful comments, which helped strengthen the paper. The work was financially supported by Maa- ja Vesitekniikan Tuki ry foundation (MVTT). We gratefully acknowledge interviewees in the Doringlaagte area, and the International Water Management Institute (IWMI) in Pretoria, South Africa and London School of Economics (LSE), with whom the primary data collection was carried out between 2014-2016.

\section{Data Availability:}

The datalcode that support the findings of this study are available on request from the corresponding author, AF. The datalcode are not publicly available because they contain information that could compromise the privacy of research participants.

\section{LITERATURE CITED}

Akhmouch, A., D. Clavreul, and P. Glas. 2018. Introducing the OECD principles on water governance. Water International 43 (1):5-12. https://doi.org/10.1080/02508060.2017.1407561

Allan, C. 2008. Can adaptive management help us embrace the Murray-Darling Basin's wicked problems? Pages 61-73 in C. PahlWostl, P. Kabat, and J. Möltgen, editors. Adaptive and integrated water management: coping with complexity and uncertainty. Springer, Berlin, Germany. https://doi.org/10.1007/978-3-540-75941-6 4

Armitage, D., R. C. de Loë, M. Morris, T. W. D. Edwards, A. K. Gerlak, R. I. Hall, D. Huitema, R. Ison, D. Livingstone, G. MacDonald, N. Mirumachi, R. Plummer, and B. B. Wolfe. 2015. Science-policy processes for transboundary water governance. Ambio 44(5):353-366. https://doi.org/10.1007/s13280-015-0644$\underline{X}$

Bacchi, C., and J. Bonham. 2014. Reclaiming discursive practices as an analytic focus: political implications. Foucault Studies 17:179-192. https://doi.org/10.22439/fs.v0i17.4298 
Batie, S. S. 2008. Wicked problems and applied economics. American Journal of Agricultural Economics 90(5):1176-1191. https://doi.org/10.1111/j.1467-8276.2008.01202.x

Baumgartner, T., and C. Pahl-Wostl. 2013. UN-Water and its role in global water governance. Ecology and Society 18(3):3. https:// doi.org/10.5751/es-05564-180303

Berkes, F. 2009. Evolution of co-management: role of knowledge generation, bridging organizations and social learning. Journal of Environmental Management 90(5):1692-1702. https://doi. org/10.1016/j.jenvman.2008.12.001

Biswas, A. K. 2008. Integrated water resources management: Is it working? International Journal of Water Resources Development 24(1):5-22.

Bocking, S. 2004. Nature's experts: science, politics, and the environment. Rutgers University Press, Piscataway, New Jersey, USA.

Boelens, R., and J. Vos. 2012. The danger of naturalizing water policy concepts: water productivity and efficiency discourses from field irrigation to virtual water trade. Agricultural Water Management 108:16-26. https://doi.org/10.1016/j.agwat.2011.06.013

Bogardi, J. J., D. Dudgeon, R. Lawford, E. Flinkerbusch, A. Meyn, C. Pahl-Wostl, K. Vielhauer, and C. Vörösmarty. 2012. Water security for a planet under pressure: interconnected challenges of a changing world call for sustainable solutions. Current Opinion in Environmental Sustainability 4(1):35-43. https://doi.org/10.1016/j.cosust.2011.12.002

Bourdieu, P. 1977. Outline of a theory of practice. R. Nice, translator. Cambridge University Press, Cambridge, UK.

Briggs, J. 2005. The use of indigenous knowledge in development: problems and challenges. Progress in Development Studies 5 (2):99-114. https://doi.org/10.1191/1464993405ps105oa

Bueger, C., and F. Gadinger. 2015. The play of international practice. International Studies Quarterly 59(3):449-460. https:// doi.org/10.1111/isqu.12202

Campbell Keller, A. 2009. Science in environmental policy: the politics of objective advice. MIT Press, Cambridge, Massachusetts.

Cash, D., W. C. Clark, F. Alcock, N. M. Dickson, N. Eckley, and J. Jäger. 2003. Salience, credibility, legitimacy and boundaries: linking research, assessment and decision making. KSG Working Papers Series. Kennedy School of Government, Harvard University, Cambridge, Massachusetts. https://doi.org/10.2139/ $\underline{\text { ssrn. } 372280}$

Cleaver, F. 1995. Water as a weapon: the history of water supply development in Nkayi District, Zimbabwe. Environment and History 1(3):313-333. https://doi.org/10.3197/096734095779522564

Cleaver, F. 1999. Paradoxes of participation: questioning participatory approaches to development. Journal of International Development 11(4):597-612. https://doi.org/10.1002/(SICI) 1099-1328(199906)11:4<597::AID-JID610>3.0.CO;2-Q

Cleaver, F. 2000. Moral ecological rationality, institutions and the management of common property resources. Development and Change 31(2):361-383. https://doi.org/10.1111/1467-7660.00158
Cleaver, F. 2012. Development through bricolage: rethinking institutions for natural resource management. First Edition. Routledge, London, UK. https://doi.org/10.4324/9781315094915

Cleaver, F. 2018. Everyday water injustice and the politics of accommodation. Pages 246-258 in R. Boelens, T. Perreault, and J. Vos, editors. Water justice. Cambridge University Press, Cambridge, UK. https://doi.org/10.1017/9781316831847.016

Cleaver, F., and L. Whaley. 2018. Understanding process, power, and meaning in adaptive governance: a critical institutional reading. Ecology and Society 23(2):49. https://doi.org/10.5751/ ES-10212-230249

Ebrahim, G. Y., K. G. Villholth, and M. Boulos. 2019. Integrated hydrogeological modelling of hard-rock semi-arid terrain: supporting sustainable agricultural groundwater use in Hout catchment, Limpopo Province, South Africa. Hydrogeology Journal 27:965-981. https://doi.org/10.1007/s10040-019-01957-6

Falkenmark, M., L. Wang-Erlandsson, and J. Rockström. 2019. Understanding of water resilience in the Anthropocene. Journal of Hydrology X 2:100009. https://doi.org/10.1016/j.hydroa.2018.100009

Fallon, A. L., K. G. Villholth, D. Conway, B. A. Lankford, and G. Y. Ebrahim. 2019. Agricultural groundwater management strategies and seasonal climate forecasting: perceptions from Mogwadi (Dendron), Limpopo, South Africa. Journal of Water and Climate Change 10(1):142-157. https://doi.org/10.2166/ wcc. 2018.042

Fischer, F. 2000. Citizens, experts, and the environment: the politics of local knowledge. Duke University Press, Durham, North Carolina, USA. https://doi.org/10.1215/9780822380283

Förster, J. J., L. Downsborough, and M. J. Chomba. 2017. When policy hits practice: structure, agency, and power in South African water governance. Society \& Natural Resources 30(4):521-536. https://doi.org/10.1080/08941920.2016.1268658

Forsyth, T. 2003. Critical political ecology: the politics of environmental science. Routledge, London, UK. https://doi. org/10.4324/9780203017562

Franks, T., and F. Cleaver. 2007. Water governance and poverty. Progress in Development Studies 7(4):291-306. https://doi. org/10.1177/146499340700700402

Frickel, S., and C. M. Rea. 2020. Drought, hurricane, or wildfire? Assessing the Trump Administration's anti-science disaster. Engaging Science, Technology, and Society 6:66. https://doi. org/10.17351/ests2020.297

Fung, A. 2006. Varieties of participation in complex governance. Public Administration Review 66:66-75. https://doi.org/10.1111/ j.1540-6210.2006.00667.x

Funtowicz, S. O., and J. R. Ravetz. 1993. Science for the postnormal age. Futures 25(7):739-755. https://doi.org/10.1016/0016-3287 (93)90022-L

Galaz, V. 2007. Water governance, resilience and global environmental change - a reassessment of integrated water resources management (IWRM). Water Science and Technology 56(4):1-9. https://doi.org/10.2166/wst.2007.530 
Garduño, H., F. van Steenbergen, and S. Foster. 2010. Sustainable groundwater management concepts \& tools: stakeholder participation in groundwater management enabling and nurturing engagement. World Bank Group Water Global Practice, Washington, D.C., USA.

Girod, B., A. Wiek, H. Mieg, and M. Hulme. 2009. The evolution of the IPCC's emissions scenarios. Environmental Science \& Policy 12(2):103-118. https://doi.org/10.1016/j.envsci.2008.12.006

Goebbel, A. 1998. Process, perception and power: notes from "participatory" research in a Zimbabwean resettlement area. Development and Change 29:277-305. https://doi. org/10.1111/1467-7660.00079

Gosling, S. N., and N. W. Arnell. 2016. A global assessment of the impact of climate change on water scarcity. Climatic Change 134:371-385. https://doi.org/10.1007/s10584-013-0853-X

Grafton, R. Q. 2017. Responding to the 'wicked problem' of water insecurity. Water Resources Management 31(10):3023-3041. https://doi.org/10.1007/s11269-017-1606-9

Grafton, R. Q., J. Williams, C. J. Perry, F. Molle, C. Ringler, P. Steduto, B. Udall, S. A. Wheeler, Y. Wang, D. Garrick, and R. G. Allen. 2018. The paradox of irrigation efficiency. Science 361 (6404):748-750. https://doi.org/10.1126/science.aat9314

Green, J. F., and W. B. Chambers. 2007. The politics of participation in sustainable development discourse. United Nations University Press, Tokyo, Japan.

Grey, D., and C. W. Sadoff. 2007. Sink or swim? Water security for growth and development. Water Policy 9(6):545-571. https:// doi.org/10.2166/wp.2007.021

Gustafsson, K. M., and R. Lidskog. 2018. Boundary organizations and environmental governance: performance, institutional design, and conceptual development. Climate Risk Management 19:1-11. https://doi.org/10.1016/j.crm.2017.11.001

Guston, D. H. 2001. Boundary organizations in environmental policy and science: an introduction. Science, Technology, \& Human Values 26(4):399-408. https://doi.org/10.1177/016224390102600401

Haas, P. M. 1992. Introduction: epistemic communities and international policy coordination. International Organization 46 (1):1-35. https://doi.org/10.1017/S0020818300001442

Haas, P. M. 2016. Epistemic communities, constructivism, and international environmental governance. Routledge, London, UK.

Hardin, G. 1968. The tragedy of the commons. Science 162:1243-1248. https://doi.org/10.1126/science.162.3859.1243

Harrington, C. 2017. The political ontology of collaborative water governance. Water International 42(3):254-270. https://doi. org/10.1080/02508060.2017.1309507

Harris, J., V. A. Brown, and J. Russell. 2010. Tackling wicked problems: through the transdisciplinary imagination. Routledge, London, UK. https://doi.org/10.4324/9781849776530

Head, B. 2010. Wicked problems in water governance: paradigm changes to promote water sustainability and address planning uncertainty. Technical Report No. 38. Urban Water Security Research Alliance, Queensland, Australia.

Hepworth, N., and S. Orr. 2013. Corporate water stewardship: exploring private sector engagement in water security. Chapter 14 in B. Lankford, K. Bakker, M. Zeitoun, and D. Conway, editors. Water security: principles, perspectives and practices. First edition. Routledge, London, UK. https://doi.org/10.4324/97802$\underline{03113202-23}$

Hickey, S., and G. Mohan, editors. 2004. From tyranny to transformation? Exploring new approaches to participation. Zed Books, London, UK.

Hope, R., T. Foster, A. Money, and M. Rouse. 2012. Harnessing mobile communications innovations for water security. Global Policy 3(4):433-442. https://doi.org/10.1111/j.1758-5899.2011.00164. $\underline{x}$

Hoppe, R., and A. Wesselink. 2014. Comparing the role of boundary organizations in the governance of climate change in three EU member states. Environmental Science \& Policy 44:73-85. https://doi.org/10.1016/j.envsci.2014.07.002

Horn, R. E., and R. P. Webber. 2007. New tools for resolving wicked problems: mess mapping and resolution mapping processes. Strategy Kinetics L.L.C., Watertown, Massachusetts, USA.

Huitema, D., E. Mostert, W. Egas, S. Moellenkamp, C. PahlWostl, and R. Yalcin. 2009. Adaptive water governance: assessing the institutional prescriptions of adaptive (co-) management from a governance perspective and defining a research agenda. Ecology and Society 14(1):26. https://doi.org/10.5751/ES-02827-140126

Hulme, M. 2009. Why we disagree about climate change: understanding controversy, inaction and opportunity. Cambridge University Press, Cambridge, UK. https://doi.org/10.1017/ CBO9780511841200

Jentoft, S., and R. Chuenpagdee, editors. 2015. Interactive governance for small-scale fisheries. Springer International, Cham, Switzerland. https://doi.org/10.1007/978-3-319-17034-3

Jolly, J. 1986. Borehole/irrigation survey and groundwater evaluation of the Doringlaagte Drainage Basin. Technical Report No. GH3495. Department of Water Affairs and Forestry, Pretoria, South Africa.

Koehler, J., P. Thomson, and R. Hope. 2015. Pump-priming payments for sustainable water services in rural Africa. World Development 74:397-411. https://doi.org/10.1016/j.worlddev.2015.05.020

Kooiman, J., M. Bavinck, R. Chuenpagdee, R. Mahon, and R. Pullin. 2008. Interactive governance and governability: an introduction. Journal of Transdisciplinary Environmental Studies 7(1):1-11.

Kooiman, J., S. Jentoft, and R. Pullin, M. Bavinck. 2005. Fish for life: interactive governance for fisheries. Amsterdam University Press, Amsterdam, The Netherlands. https://doi. org/10.1515/9789048505326

Kosack, S., and A. Fung. 2014. Does transparency improve governance? Annual Review of Political Science 17(1):65-87. https://doi.org/10.1146/annurev-polisci-032210-144356 
Kreuter, M. W., C. De Rosa, E. H. Howze, and G. T. Baldwin. 2004. Understanding wicked problems: a key to advancing environmental health promotion. Health Education \& Behavior 31(4):441-454. https://doi.org/10.1177/1090198104265597

Kummu, M., J. H. A. Guillaume, H. de Moel, S. Eisner, M. Flörke, M. Porkka, S. Siebert, T. I. E. Veldkamp, and P. J. Ward. 2016. The world's road to water scarcity: shortage and stress in the 20th century and pathways towards sustainability. Scientific Reports 6:38495. https://doi.org/10.1038/srep38495

Kustermans, J. 2016. Parsing the practice turn: practice, practical knowledge, practices. Millennium: Journal of International Studies 44(2):175-196. https://doi.org/10.1177/0305829815613045

Lankford, B. 2001. Red routes on blue rivers: strategic water management for the Ruaha River Basin, Tanzania. International Journal of Water Resources Development 17(3):427-444. https:// doi.org/10.1080/07900620120065183

Lankford, B., and T. Beale. 2007. Equilibrium and nonequilibrium theories of sustainable water resources management: dynamic river basin and irrigation behaviour in Tanzania. Global Environmental Change 17(2):168-180. https://doi.org/10.1016/j. gloenvcha.2006.05.003

Lankford, B., A. Closas, J. Dalton, E. López Gunn, T. Hess, J. W. Knox, S. van der Kooij, J. Lautze, D. Molden, S. Orr, J. Pittock, B. Richter, P. J. Riddell, C. A. Scott, J.-P. Venot, J. Vos, and M. Zwarteveen 2020. A scale-based framework to understand the promises, pitfalls and paradoxes of irrigation efficiency to meet major water challenges. Global Environmental Change 65:102182. https://doi.org/10.1016/j.gloenvcha.2020.102182

Lankford, B., and N. Hepworth. 2010. The cathedral and the bazaar: monocentric and polycentric river basin management. Water Alternatives 3(1):82-101.

Lankford, B., D. Merrey, J. Cour, and N. Hepworth. 2007. From integrated to expedient: an adaptive framework for river basin management in developing countries. International Water Management Institute, Colombo, Sri Lanka.

Leal, P. A. 2010. Participation: the ascendancy of a buzzword in the neo-liberal era. Pages 89-100 in A. Cornwall and D. Eade, editors. Deconstructing development discourse: buzzwords and fuzzwords. Practical Action, Warwickshire, UK.

Lie, J. 2007. Global climate change and the politics of disaster. Sustainability Science 2(2):233-236. https://doi.org/10.1007/ s11625-007-0026-9

Liebman, J. C. 1976. Some simple-minded observations on the role of optimization in public systems decision-making. Interfaces 6(4):102-108. https://doi.org/10.1287/inte.6.4.102

Masiyandima, M., I. Van Der Stoep, T. Mwanasawani, and S. C. Pfupajena. 2002. Groundwater management strategies and their implications on irrigated agriculture: the case of Dendron aquifer in Northern Province, South Africa. Physics and Chemistry of the Earth 27(11-22):935-940. https://doi.org/10.1016/S1474-7065 (02)00096-7

Mason, N., and R. Calow. 2012. Water security: from abstract concept to meaningful metrics: an initial overview of options. Overseas Development Institute, London, UK.
Meadow, A. M., D. B. Ferguson, Z. Guido, A. Horangic, G. Owen, and T. Wall. 2015. Moving toward the deliberate coproduction of climate science knowledge. Weather, Climate, and Society 7(2):179-191. https://doi.org/10.1175/WCASD-14-00050.1

Mehta, L. 2000. Water for the twenty-first century: challenges and misconceptions. IDS Working Paper 111. Institute of Development Studies, Brighton, UK.

Meissner, R. 2005. Interest groups as local stakeholders involved in the water politics of a transboundary river: the case of the proposed Epupa Dam across the Kunene River. Pages 101-121 in L. Wirkus, editor. Water, development and cooperationcomparative perspective: Euphrates-Tigris and Southern Africa. Bonn International Center for Conversion, Bonn, Germany. [online] URL: https://www.bicc.de/uploads/tx_bicctools/paper46. pdf

Meissner, R. 2014. Who wants to be an agent? A framework to analyse water politics and governance. Water SA 40(1):1. https:// doi.org/10.4314/wsa.v40i1.1

Meissner, R. 2016a. The relevance of social theory in the practice of environmental management. Science and Engineering Ethics 22(5):1345-1360. https://doi.org/10.1007/s11948-015-9700-y

Meissner, R. 2016b. Concepts and views from international relations and their potential contribution to impact assessment thinking and practice. Politikon 43(3):411-427. https://doi. org/10.1080/02589346.2016.1212529

Meissner, R., N. Funke, and K. Nortje. 2016. The politics of establishing catchment management agencies in South Africa: the case of the Breede-Overberg Catchment Management Agency. Ecology and Society 21(3):26. https://doi.org/10.5751/ES-08417-210326

Molle, F. 2008. Nirvana concepts, storylines and policy models: Insights from the water sector. Water Alternatives 1(1):131-156.

Mollinga, P. P. 2001. Water and politics: levels, rational choice and South Indian canal irrigation. Futures 33(8-9):733-752. https://doi.org/10.1016/S0016-3287(01)00016-7

Mollinga, P. P. 2008. Water, politics and development: framing a political sociology of water resources management. Water Alternatives 1(1):7-23.

Mollinga, P. P., R. S. Meinzen-Dick, and D. J. Merrey. 2007. Politics, plurality and problemsheds: a strategic approach for reform of agricultural water resources management. Development Policy Review 25(6):699-719. https://doi. org/10.1111/j.1467-7679.2007.00393.x

Moore, M.-L. 2013. Perspectives of complexity in water governance: local experiences of global trends. Water Alternatives 6(3):487-505.

Morozov, E. 2013. To save everything, click here: technology, solutionism and the urge to fix problems that don't exist. Penguin, London, UK.

Mosse, D. 1995. Social analysis in participatory rural development. International Institute for Environment and Development, London, UK. 
Mtisi, S., and A. Nicol. 2015. Water politics in Eastern and Southern Africa. Pages 84-104 in R. Munck, N. Asingwire, H. Fagan, and C. Kabonesa, editors. Water and development: good governance after neoliberalism. Zed Books, London, UK. https:// doi.org/10.5040/9781350223899.ch-004

Murphy, D. 2012. The architecture of failure. Zero Books, Winchester, UK.

North, D. C. 1990. Institutions, institutional change and economic performance. Cambridge University Press, Cambridge, UK. https://doi.org/10.1017/CBO9780511808678

Ober, K., and P. Sakdapolrak. 2017. How do social practices shape policy? Analysing the field of 'migration as adaptation' with Bourdieu's 'theory of practice.' Geographical Journal 183 (4):359-369. https://doi.org/10.1111/geoj.12225

Organisation for Economic Co-operation and Development (OECD). 2015. OECD principles on water governance. OECD, Paris, France. [online] URL: https://www.oecd.org/cfe/ regionaldevelopment/OECD-Principles-on-Water-Governance-en. pdf

Pahl-Wostl, C., L. Lebel, C. Knieper, and E. Nikitina. 2012. From applying panaceas to mastering complexity: toward adaptive water governance in river basins. Environmental Science \& Policy 23:24-34. https://doi.org/10.1016/j.envsci.2012.07.014

Pielke, R. A., Jr. 2007. The honest broker. Cambridge University Press, Cambridge, UK.

Reed, M. S. 2008. Stakeholder participation for environmental management: a literature review. Biological Conservation 141 (10):2417-2431. https://doi.org/10.1016/j.biocon.2008.07.014

Rittel, H. W. J., and M. M. Webber. 1973. Dilemmas in a general theory of planning. Policy Sciences 4(2):155-169. https://doi. org/10.1007/bf01405730

Rockström, J., W. Steffen, K. Noone, Å. Persson, F. S. Chapin III, E. F. Lambin, T. M. Lenton, M. Scheffer, C. Folke, H. J. Schellnhuber, et al. 2009. A safe operating space for humanity. Nature 461:472-475. https://doi.org/10.1038/461472a

Rogers, P., and A. W. Hall. 2003. Effective water governance. Global Water Partnership Technical Committee (TEC) Background Papers no. 7. Global Water Partnership, Stockholm, Sweden.

Saravanan, V. S. 2010. Movers, shakers and power brokers. Agents in negotiated water management in the Indian Himalayas. Pages 27-61 in P. P. Mollinga, A. Bhat, and V. S. Saravan, editors. When policy meets reality. Political dynamics and the practice of integration in water resources management reform. LIT, Bonn, Germany.

Schreiner, B. 2013. Viewpoint - Why has the South African national water act been so difficult to implement? Water Wheel 12(5):38-41.

Shapiro, M. 1988. Judicial selection and the design of clumsy institutions. Southern California Law Review 61(3):1555-1569.

Sojamo, S. 2015. Unlocking the "prisoner's dilemma" of corporate water stewardship in South Africa-exploring corporate power and legitimacy of engagement in water management and governance. Sustainability 7(6):6893-6918. https://doi.org/10.3390/ $\underline{\text { su7066893 }}$

Stacey, R. D. 2011. Strategic management and organisational dynamics: the challenge of complexity to ways of thinking about organisations. Sixth edition. Financial Times/Prentice Hall, Hoboken, New Jersey, USA.

Stirling, A. 2010. Keep it complex. Nature 468:1029-1031. https:// doi.org/10.1038/4681029a

Stone, D. A. 1989. Causal stories and the formation of policy agendas. Political Science Quarterly 104(2):281-300. https://doi. org/10.2307/2151585

Sutherland, W. J., D. Spiegelhalter, and M. Burgman. 2013. Twenty tips for interpreting scientific claims. Nature 503 (7476):335-337. https://doi.org/10.1038/503335a

van Koppen, B. V., and B. Schreiner. 2014. Priority general authorisations in rights-based water use authorisation in South Africa. Water Policy 16:59-77. https://doi.org/10.2166/wp.2014.110

Vogel, C., S. C. Moser, R. E. Kasperson, and G. D. Dabelko. 2007. Linking vulnerability, adaptation, and resilience science to practice: pathways, players, and partnerships. Global Environmental Change 17(3-4):349-364. https://doi.org/10.1016/ j.gloenvcha.2007.05.002

Vörösmarty, C. J., P. Green, J. Salisbury, and R. B. Lammers. 2000. Global water resources: vulnerability from climate change and population growth. Science 289:284-288. https://doi.org/10.1126/ science.289.5477.284

Wallis, P. J., and R. L. Ison. 2011. Appreciating institutional complexity in water governance dynamics: a case from the Murray-Darling Basin, Australia. Water Resources Management 25(15):4081-4097. https://doi.org/10.1007/s11269-011-9885-Z

Wehn, U., K. Collins, K. Anema, L. Basco-Carrera, and A. Lerebours. 2018. Stakeholder engagement in water governance as social learning: lessons from practice. Water International 43 (1):34-59. https://doi.org/10.1080/02508060.2018.1403083

Wester, P. 2008. Shedding the waters: institutional change and water control in the Lerma-Chapala Basin, Mexico. Dissertation. Wageningen University, Wageningen, The Netherlands.

Wester, P., and J. Bron. 1998. Coping with water: water management in flood control and drainage systems in Bangladesh. ILRI, Nairobi, Kenya.

Wester, P., D. J. Merrey, and M. de Lange. 2003. Boundaries of consent: stakeholder representation in River Basin management in Mexico and South Africa. World Development 31(5):797-812. https://doi.org/10.1016/S0305-750X(03)00017-2

White, S. C. 1996. Depoliticising development: the uses and abuses of participation. Development in Practice 6(1):6-15. https://doi. org/10.3362/9780855987015.007

World Meteorological Organization. 1992. The Dublin Statement and Report of the Conference. International Conference on Water and the Environment. World Meteorological Organization, Geneva, Switzerland. 
Zeitoun, M. 2011. The global web of national water security. Global Policy 2(3):286-296. https://doi.org/10.1111/

j.1758-5899.2011.00097.x

Zeitoun, M., B. Lankford, T. Krueger, T. Forsyth, R. Carter, A. Y. Hoekstra, R. Taylor, O. Varis, F. Cleaver, R. Boelens, L. Swatuk, D. Tickner, C. A. Scott, N. Mirumachi, and N. Matthews. 2016. Reductionist and integrative research approaches to complex water security policy challenges. Global Environmental Change 39:143-154. https://doi.org/10.1016/j.gloenvcha.2016.04.010

Zeitoun, M., and J. Warner. 2006. Hydro-hegemony - a framework for analysis of trans-boundary water conflicts. Water Policy 8 (5):435-460. https://doi.org/10.2166/wp.2006.054 


\section{APPENDIX I. CASE STUDY DETAILS}

Further information regarding the South African case study detailed in the article can be found below, separated into the four components of the governance solutionscape.

\section{Locating the Doringlaagte}

The 'Doringlaagte' is the local name for a small sub-catchment of the Hout Catchment within the Limpopo River Basin in South Africa. The Hout Catchment is located $60 \mathrm{~km}$ northwest of Polokwane city and has an area of 2,478 $\mathrm{km}^{2}$. The climate is semi-arid, with an annual long-term mean precipitation of $407 \mathrm{~mm}$ /year (see Ebrahim et al. 2019 for detailed hydrogeological and climatological information).

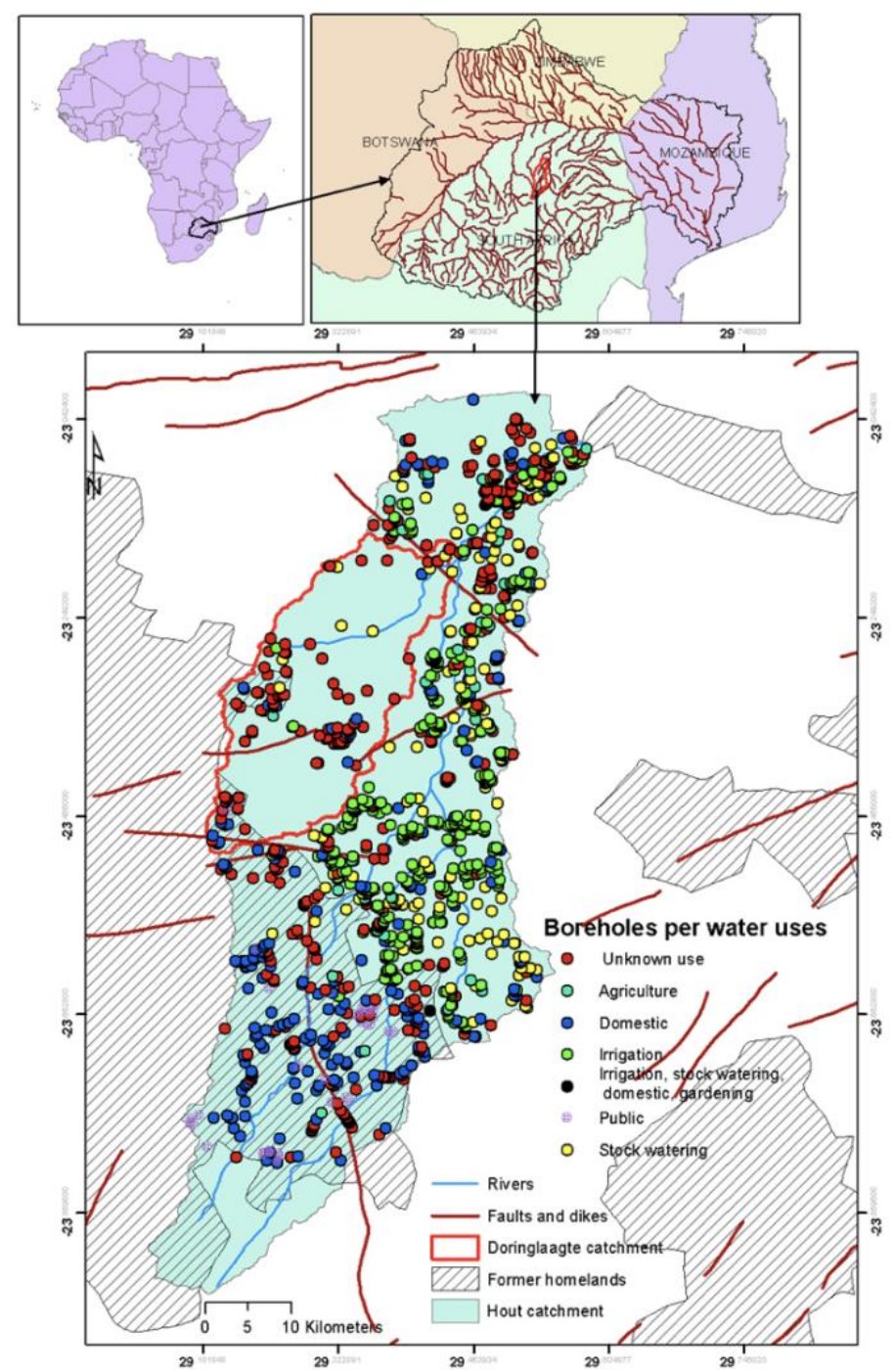

Fig. A1.1. The study area's location within the Limpopo basin. The area lined in red denotes the Doringlaagte, where the majority of the case study research was carried out (source: Fallon et al. 2019).

The following sections describe in more detail the different solutionscape dimensions pertaining to the case study, as well as more contextual information for South Africa.

\section{Science and research}

Research regarding the groundwater status of the catchment has been carried out on and off for the past few decades, although there is little evidence of significant change in groundwater-use due to these studies. More recent research has been focused on groundwater modelling (by the International Water 
Management Institute) due to low groundwater data availability (most groundwater level recordings do not go back far enough to provide a clear picture of the aquifer's status) (Ebrahim et al. 2019). This work has been carried out alongside contact with some commercial farmers, with interest paid to local knowledge of the environment. However, gaining access to boreholes for monitoring data has been a continued issue. Gaps in monitoring and regulation have resulted in the production of misinformation, both consciously and unconsciously. For example, several commercial farmers externalized liability for groundwater exploitation to nearby towns and (unverified) government-built dams upstream, while legitimizing their own water use with narratives of family farming legacies and providing food security for the country. However, the high interest in Limpopo-wide groundwater status reports indicated that these perceptions are not infallible, and better data could go a long way in changing the practices currently undertaken in the catchment.

\section{Policy, policymakers and partnerships}

South Africa's 1998 National Water Act (Act 36) was deemed an archetype of water legislation around the world, hailed for its progressive inclusion of IWRM principles and fundamental reformation of the previous apartheid-era Water Act of 1956, which was racially discriminatory and based on European legislation (typically made for water-rich countries, unlike the water-scarce South Africa). However, implementation has been weak, and has been criticised for the protection of pre-1994 licenses as 'existing lawful use' which accommodates users with entitlements from the earlier system based on riparian rights and perpetuates racial inequalities (van Koppen and Schreiner, 2014).

Decentralization of water management responsibilities to Catchment Management Agencies (CMAs) was central in the water reform process in post-Apartheid South Africa (Kemerink et al. 2013). However, as described by Schreiner (2013), there was widespread failure in the ambitious target of establishing 19 CMAs, due to poor target-setting and accountability, underestimation of the complexities of both departmental and sectoral transformation, lack of capacity in regional offices of the Department of Water Affairs (now Department of Water and Sanitation, DWS), and the illegitimacy of decisions made regarding such institutional policy and process. This manifested across the country in multiple policy adjustments, non-existent stakeholder engagement, limited progress in establishing CMAs, alongside the continuation of apartheid-era Irrigation Boards (consisting predominantly of white male commercial farmers). Unfortunately, successive Ministers have come and gone, each with a different view of policy and strategy leaving the broader water sector with uncertain intent and an inability to unlock what are deeply complex issues.

Almost all interviewed commercial farmers in the catchment reported very weak formal governance by the government (in terms of monitoring and regulation of water use), and trust between the farming community and the regional DWS office is low due to stagnating communication regarding the approval of a new Water User Association (WUA), which is desired by the farming community as a way to have more authority and coordination over water use in the catchment (Fallon et al. 2019).

Water licenses are weakly implemented in the study area, leading to concerns of some commercial farms exceeding licenses, illegal borehole drilling and illegal dam-building along the river. Issues with the 'Blue Scorpions' - the government's Environmental Management Inspectorate responsible for verifying commercial water use - were reported by two game farmers during interviews, who had unsuccessfully reported illegal drilling in the area to them. Licensing data obtained from DWS showed that $91 \%$ of water licenses in the area were 'yet to be verified' (as of 2017). Water licenses are approved based on farmer's declared needs and satellite imagery of irrigatable land. Groundwater monitoring by DWS is also inadequate; a hydrogeologist from DWS reported severe deterioration in monitoring infrastructure across the catchment (and in the wider Limpopo River Basin) and rapid loss of skilled personnel within the department, with a high staff turnover rate. This was perceived to be undercutting 
efforts to produce quarterly groundwater status reports for the basin, as well as deteriorating trust between DWS and farmers, who became fatigued with having to re-establish communication and relationships every time existing staff left.

Water user associations, where they have been established, play an important role in compliance monitoring within their areas of operation, and as such these associations are understood to be a key local actor in supporting the DWS in ensuring users comply with license conditions. It is effectively in the best interest of both the association and the DWS for this type of local regulation to support improved water resource management. As such, the frustration of the agricultural sector at the poor pace of institutional reform is palpable.

Communication facilitated by researchers (Fallon et al. 2019) helped establish trust between a few hydrologists within DWS and local farmers, and led to the distribution of quarterly groundwater status reports through a mailing list (although this has since been halted due to the retirement of the author of the report, and lack of a replacement). The emergence of this process helped circumnavigate failing official channels of communication and promote knowledge-sharing.

There was little coordination observed between DWS and related governmental bodies, such as the Department of Land Reform and Rural Affairs, regarding the linkages between groundwater use and land acquisitions. A country-wide attempt has been long underway to retract historical dispossession of black communities from land and water rights appropriated by the Land Acts of 1913 and 1936, and the 1912 Irrigation Act, under the apartheid era (van Koppen and Schreiner 2014). However, water remains predominantly in the hands of white South Africans, and groundwater is still intrinsically linked to land ownership due to prior riparian rights, largely condoned by the 'existing lawful use' section of the 1998 National Water Act (NWA). Several farmers interviewed in the Doringlaagte regarded the water abstracted within their farm boundaries as belonging to them, despite water rights in South Africa shifting from riparian rights to public trust with the NWA. However, younger farmers were more supportive of the Public Trust Doctrine, suggesting a generational shift in perspectives on water rights.

\section{Practice and technology}

In the Doringlaagte, most groundwater management remains predominantly within socially-embedded institutions, with individual day-to-day actions and some 'gentlemen's agreements' between farmers (Fallon et al. 2018). Relations between white and black farmers remain detached, with white commercial farmers constituting the primary resource users. These weak relationships and significant power asymmetries are primarily due to the historical racial legacies that prevail across South Africa more broadly, though racial prejudices seemed to be slowly changing amongst some farmers. A few commercial farmers in the area have been involved in government-led mentorship programs, aimed at training black emerging farmers on how to run a farm, and helping them establish a livelihood. The scheme was generally well-received, and one farmer interviewed felt that despite 'teething issues', it was an important step towards equality. However, one interviewee did not see this as a good programme, alleging nepotism within the government regarding who received this training (some of whom had little interest in farming), and an associated increase in mistrust between the government, commercial farmers, and emerging farmers. There was also a discreet concern that some emerging farmers were not interested in long-term groundwater management, and one commercial farmer felt that they were better equipped at managing groundwater due to a more intimate, generational knowledge of the local environment. It therefore seems that existing practices, including practical knowledge and cultural norms, dominate the groundwater governance arrangement within the Doringlaagte, which have proven difficult to change (particularly with poor policy implementation and unequal participation in decision-making processes). 


\section{Participation and engagement}

As shown so far within this case study, there are power asymmetries occurring in the study area. While a WUA is yet to be officially established, the local Agricultural Union has been gaining legitimacy as an authoritative power regarding groundwater management, partly due to its endurance (its ancestral institution being the Irrigation Board). This decentralization of power to the local level may seem appealing in terms of 'good governance' principles. However, without official support from the government there is no requirement for an inclusive association, which means no black emerging farmers are included in meetings (Fallon et al. 2019). Thus, without support, existing power asymmetries are perpetuated and water management decisions remain with the most powerful players in an 'echo-chamber' whereby few new ideas are circulated. When stakeholder participation is inadequate, it is easy for powerful actors to perpetuate their own narratives. For example, the dominance of the agricultural union by white commercial farmers was legitimized by their much higher consumption of water (thus they could make the biggest impact, positively or negatively). However, having no alternative perspectives, values or needs present in meetings meant the same narratives and decisions were maintained. Uncritical participation that is unsupported by appropriately implemented land and water policies cannot therefore address this deeply embedded legacy. In this sense, participation in the Doringlaagte remains an instrument for efficiency and a display of inclusion, rather than one of transformation and empowerment (as per White 1996). Thus, existing practices endure.

\section{$\underline{\text { Additional references }}$}

Kemerink, J.S., Méndez, L.E., Ahlers, R., Wester, P., Van Der Zaag, P., 2013. The question of inclusion and representation in rural South Africa: Challenging the concept of water user associations as a vehicle for transformation. Water Policy 15: 243-257. DOI: 10.2166/wp.2012.127 